\title{
Abomasal infusion of ground corn and ammonium chloride in early-lactating Holstein-Friesian dairy cows to induce hindgut and metabolic acidosis
}

\author{
Sanne van Gastelen, ${ }^{1 *} \odot$ Jan Dijkstra, ${ }^{2} \oplus$ Kelly Nichols, ${ }^{2} \odot$ and André Bannink ${ }^{1}$ \\ ${ }^{1}$ Wageningen Livestock Research, Wageningen University \& Research, $6700 \mathrm{AH}$, Wageningen, the Netherlands \\ ${ }^{2}$ Animal Nutrition Group, Wageningen University \& Research, $6700 \mathrm{AH}$, Wageningen, the Netherlands
}

\begin{abstract}
Next to rumen acidosis, other forms of acidosis may also affect lactational performance of cows. Therefore, the effects of hindgut acidosis, induced via abomasal infusion of ground corn, and metabolic acidosis, induced via abomasal infusion of $\mathrm{NH}_{4} \mathrm{Cl}$, were studied in cows in early lactation. Observations were made on intake and digestibility of nutrients, lactation performance, energy and $\mathrm{N}$ partitioning, blood acid-base status, and rumen and hindgut fermentation characteristics. In a $6 \times 6$ Latin square design, 6 rumen-fistulated, secondlactation Holstein-Friesian dairy cows $(48 \pm 17 \mathrm{~d}$ in milk) were subjected to $5 \mathrm{~d}$ of continuous abomasal infusions of water as control, or solutions of $2.5 \mathrm{~mol}$ of $\mathrm{NH}_{4} \mathrm{Cl} / \mathrm{d}, 5.0 \mathrm{~mol}$ of $\mathrm{NH}_{4} \mathrm{Cl} / \mathrm{d}, 3.0 \mathrm{~kg}$ of ground corn/d, or the combination of ground corn with either of the 2 $\mathrm{NH}_{4} \mathrm{Cl}$ levels, followed by $2 \mathrm{~d}$ of rest. Treatment solutions were administered via peristaltic pumps through infusion lines attached to the rumen cannula plug and an abomasal infusion line with a flexible disk (equipped with holes to allow digesta passage) to secure its placement through the sulcus omasi. A total mixed ration consisting of $70 \%$ grass silage and $30 \%$ concentrate (on dry matter basis) was fed at $95 \%$ of ad libitum intake of individual cows. The experiment was conducted in climate respiration chambers to determine feed intake, lactation performance, and energy and $\mathrm{N}$ balance. $\mathrm{Ab}-$ omasal infusion of $\mathrm{NH}_{4} \mathrm{Cl}$ affected the acid-base status of the cows, but more strongly when in combination with abomasal infusion of ground corn. Metabolic acidosis (defined as a blood $\mathrm{pH}<7.40$, blood $\mathrm{HCO}_{3}$ concentration $<25.0 \mathrm{mmol} / \mathrm{L}$, and a negative base excess) was observed with $5.0 \mathrm{~mol}$ of $\mathrm{NH}_{4} \mathrm{Cl} / \mathrm{d}, 3.0 \mathrm{~kg}$ of ground corn $/ \mathrm{d}+2.5 \mathrm{~mol}$ of $\mathrm{NH}_{4} \mathrm{Cl} / \mathrm{d}$, and $3.0 \mathrm{~kg}$ of ground corn/d $+5.0 \mathrm{~mol}$ of $\mathrm{NH}_{4} \mathrm{Cl} / \mathrm{d}$. Metabolic acidosis was associated with decreased milk lactose content,
\end{abstract}

Received July 16, 2020.

Accepted October 17, 2020.

*Corresponding author: sanne.vangastelen@wur.nl metabolic body weight, energy retained as protein, and fecal $\mathrm{N}$ excretion, and increased urine $\mathrm{N}$ excretion, and tended to decrease intake of nutrients. Digestibility of several nutrients increased with $5.0 \mathrm{~mol}$ of $\mathrm{NH}_{4} \mathrm{Cl} / \mathrm{d}$, likely as a result of decreased intake. Abomasal ground corn infusion resulted in hindgut acidosis, where fecal $\mathrm{pH}$ decreased from 6.86 without ground corn to 6.00 with ground corn, regardless of $\mathrm{NH}_{4} \mathrm{Cl}$ level. The decrease in fecal $\mathrm{pH}$ was likely the result of increased hindgut fermentation, evidenced by increased fecal volatile fatty acid concentrations. Hindgut acidosis was associated with decreased digestibility of nutrients, except for starch, which increased, and crude fat, which was not affected. No systemic inflammatory response was observed, suggesting that the hindgut epithelium was not severely affected by the more acidic conditions or barrier damage. Abomasal infusion of ground corn increased milk yield, milk protein and lactose yield, fecal $\mathrm{N}$ excretion, $\mathrm{N}$ use efficiency, and total energy retained as well as energy retained in fat, and reduced milk fat content and urine $\mathrm{N}$ excretion.

Key words: dairy cow, early lactation, metabolic acidosis, hindgut acidosis

\section{INTRODUCTION}

In dairy cattle, several forms of acidosis related to nutrition can be distinguished. Rumen acidosis has been reviewed extensively, whereas the roles of hindgut and metabolic acidosis have received less attention until recently (Gressley et al., 2011; Plaizier et al., 2018). High-yielding dairy cows commonly suffer from production-limiting diseases, including milk fever and ketosis (Mulligan and Doherty, 2008). Many of these diseases interact, and it has only recently been recognized that prevention of these diseases is closely linked with addressing the gastrointestinal health of dairy cows (e.g., Enemark, 2008; Mulligan and Doherty, 2008). Risks of excessive hindgut fermentation and associated organic acid production increase with dietary fermentable carbohydrate content (starch content in particular) and with feed intake level (associated with reduced retention time of feed in the rumen; Gressley 
et al., 2011). Most of the VFA produced in the hindgut are absorbed through the intestinal epithelium (Argenzio et al., 1975; Gressley et al., 2011), but excessive fermentation in the hindgut can lead to an accumulation of VFA and other acids (Gressley et al., 2011) and consequently a decrease in digesta $\mathrm{pH}$. The hindgut is less capable than the rumen of maintaining a stable digesta $\mathrm{pH}$, due to the lack of bicarbonate from salivary secretion, absence of protozoa, and differences in the gut epithelium structure (Immig, 1996; Gressley et al., 2011; Dijkstra et al., 2012). A decrease in digesta $\mathrm{pH}$ due to hindgut fermentation may change the composition and functioning of hindgut microbial populations, may damage the gut epithelium, and consequently may affect both animal production and health (Gressley et al., 2011).

In addition to hindgut acidosis, cows in early lactation are at risk of developing metabolic acidosis associated with dietary factors, or as a consequence of rumen and hindgut acidosis (Enemark et al., 2002). Blood plasma $\mathrm{pH}$ is determined by several factors, including partial pressure of $\mathrm{CO}_{2}$, concentration of nonvolatile weak buffers such as albumins and globulins, and strong ion difference (the difference between strong cations and anions; Stewart, 1983). The latter is of particular relevance in manipulation of DCAD [defined as $\mathrm{mEq}$ of $\left(\mathrm{Na}^{+}+\mathrm{K}^{+}\right)-\left(\mathrm{Cl}^{-}+\mathrm{S}^{2-}\right)$ per $\mathrm{kg}$ of DM; Afzaal et al., 2004] and its role in preventing hypocalcemia in the periparturient period (Charbonneau et al., 2006). With increased consideration of DCAD in dry-cow nutrition, interest has also grown in the effects of DCAD on lactating dairy cows. Some studies have suggested that there could be an optimal DCAD for maximizing feed consumption and milk yield. For example, Constable et al. (2017) suggested that the optimal DCAD is approximately $+400 \mathrm{mEq} / \mathrm{kg}$ of $\mathrm{DM}$ for cows in early lactation and between +275 to $+400 \mathrm{mEq} / \mathrm{kg}$ of DM for cows in mid-lactation. Hu and Murphy (2004) observed in a meta-analysis that DMI and milk yield increased quadratically with DCAD up to $+400 \mathrm{mEq} /$ $\mathrm{kg}$ of $\mathrm{DM}$ and $+340 \mathrm{mEq} / \mathrm{kg}$ of $\mathrm{DM}$, respectively. The response in milk yield is most likely related to increased energy and nutrient supply to support milk. Reduced palatability of the diet and induced metabolic acidosis due to lower cation-to-anion ratio have been proposed as the main reasons for reduced DMI (Zimpel et al., 2018). Apart from dietary change in DCAD to prevent hypocalcemia, dietary manipulation of DCAD can be seen as an experimental model that enables studying the consequences of metabolic acidosis.

Limited research has been performed in which experimentally induced hindgut acidosis and metabolic acidosis were studied simultaneously in early-lactation dairy cows. This is of great interest, because a relation may exist between acidosis in the hindgut and the occurrence of metabolic acidosis, especially when acidosis in the hindgut is accompanied by metabolic consequences, affecting acid-base status of the cow, and vice versa. The aims of the current study were (1) to induce hindgut and metabolic acidosis via abomasal infusion of ground corn and $\mathrm{NH}_{4} \mathrm{Cl}$, respectively, and (2) to determine the effects of these physiological states on feed intake, apparent total-tract digestibility (ATTD) of nutrients, energy and $\mathrm{N}$ partitioning, lactation performance, blood acid-base status, respiratory and nutrient status, and rumen and hindgut fermentation characteristics.

We hypothesized that abomasally infused ground corn would be fermented in the hindgut, produce VFA, and subsequently decrease digesta $\mathrm{pH}$, resulting in hindgut acidosis. Abomasal infusion of $\mathrm{NH}_{4} \mathrm{Cl}$ was expected to result in metabolic acidosis, where the absorption of $\mathrm{Cl}$ from the gastrointestinal tract would reduce the strong ion difference in blood and decrease blood $\mathrm{pH}$. When both ground corn and $\mathrm{NH}_{4} \mathrm{Cl}$ were infused into the abomasum, we expected to induce both hindgut and metabolic acidosis, with metabolic acidosis being more severe compared with only $\mathrm{NH}_{4} \mathrm{Cl}$ infusion because of a combined effect of both types of acidosis on the acid-base status of the cow.

\section{MATERIALS AND METHODS}

\section{Experimental Design and Housing}

The experiment was conducted from August until October 2018 at the animal research facilities of Wageningen University \& Research (Wageningen, the Netherlands), under the Dutch Law on Animal Experiments in accordance with European Union Directive 2010/63, and approved by the Central Committee of Animal Experiments (The Hague, the Netherlands; 2018.D-0013.001).

Six rumen-fistulated, second-lactation HolsteinFriesian dairy cows with an average milk production $( \pm \mathrm{SD})$ of $34.2 \pm 2.87 \mathrm{~kg} / \mathrm{d}$ at $48 \pm 17$ DIM at the start of the experiment were randomly assigned to a $6 \times 6$ Latin square design with 6 treatments. Each experimental period $(\mathrm{n}=6)$ consisted of $120 \mathrm{~h}$ of continuous abomasal infusion followed by $48 \mathrm{~h}$ of rest (Figure 1 ). Cows were adapted to the experimental conditions for $19 \mathrm{~d}$ before the first experimental period. For the first $14 \mathrm{~d}$ of adaptation, cows were housed individually in tiestalls to become adapted to the basal diet as well as the restriction in movement. For the last $5 \mathrm{~d}$ of adaptation as well as for the 6 consecutive experimental peri- 


\begin{tabular}{|c|c|c|c|c|c|c|}
\hline \multicolumn{7}{|c|}{ Experimental period } \\
\hline d1 & d2 & d3 & $\mathrm{d} 4$ & d5 & d6 & d7 \\
\hline Inf. d1 & Inf. d2 & Inf. d3 & Inf. $d 4$ & Inf. d5 & & \\
\hline \multicolumn{5}{|c|}{ Balance period } & & \\
\hline & & \multicolumn{3}{|c|}{ Gaseous exchange } & & \\
\hline
\end{tabular}

Figure 1. Design of a single 7-d experimental period. Inf. d1 to Inf. d5 $=120$-h abomasal infusion period beginning at $0900 \mathrm{~h}$ on $\mathrm{d} 1 \mathrm{and}$ ending at $0900 \mathrm{~h}$ on $\mathrm{d} 6$ of each experimental period. The infusion period was followed by a 48 -h washout period. Balance period $=71-\mathrm{h}$ period of total manure collection with milk and feces samples from $1000 \mathrm{~h}$ on d 3 until $0900 \mathrm{~h}$ on $\mathrm{d}$ 6. Gaseous exchange $=48$-h period of gas production and consumption measured from $0800 \mathrm{~h}$ on $\mathrm{d} 4$ until $0800 \mathrm{~h}$ on $\mathrm{d} 6$.

ods, cows were housed individually in identical climate respiration chambers $(\mathbf{C R C})$.

\section{Diet and Feeding}

Cows were fed a TMR consisting of $70 \%$ grass silage and $30 \%$ concentrate on a DM basis (Table 1). To de-

Table 1. Chemical composition ( $\mathrm{g} / \mathrm{kg}$ of DM, unless otherwise stated) of the TMR ingredients (grass silage and concentrate; analyzed) and of the complete $\mathrm{TMR}^{1}$ (calculated)

\begin{tabular}{lccc}
\hline & $\begin{array}{c}\text { Grass } \\
\text { silage }^{2}\end{array}$ & Concentrate $^{3}$ & TMR \\
\hline DM (g/kg of product) & 549 & 891 & 447 \\
OM & 900 & 917 & 905 \\
CP & 171 & 181 & 174 \\
Crude fat & 37 & 94 & 54 \\
GE $^{4}(\mathrm{MJ} / \mathrm{kg}$ of DM) & 19.0 & 19.3 & 19.1 \\
NDF & 508 & 318 & 451 \\
ADF & 284 & 192 & 256 \\
ADL & 13 & 19 & 15 \\
Starch & -5 & 150 & 45 \\
Sugar & 98 & 71 & 90 \\
NE ${ }^{6}$ (MJ/kg of DM) & 6.2 & 8.5 & 6.9 \\
DVE & 66 & 157 & 93 \\
OEB $^{8}$ & 37 & -16 & 21 \\
Sodium & 4.6 & 2.7 & 4.0 \\
Potassium & 30.9 & 12.0 & 25.2 \\
Chloride $_{\text {Sulfur }}$ & 19.5 & 4.0 & 14.9 \\
\hline
\end{tabular}

${ }^{1}$ The TMR was composed of $57 \%$ grass silage, $15 \%$ concentrate, and $28 \%$ water on product basis, which was equal to $700 \mathrm{~g} / \mathrm{kg}$ of DM grass silage and $300 \mathrm{~g} / \mathrm{kg}$ of DM concentrate.

${ }^{2}$ Ensiling characteristics: acetic acid $=7 \mathrm{~g} / \mathrm{kg}$ of DM, lactic acid $=11$ $\mathrm{g} / \mathrm{kg}$ of $\mathrm{DM}$, ammonia- $\mathrm{N}=6 \%$ total $\mathrm{N}$, and $\mathrm{pH}=5.6 . \mathrm{DCAD}=184$ $\mathrm{mEq} / \mathrm{kg}$ of DM.

${ }^{3}$ Concentrate contained $(\mathrm{g} / \mathrm{kg}$ of DM $)$ : wheat $=200$, soybean hulls $=$ 200, rumen-protected soybean meal (Rumi-S, NuScience, Utrecht, the Netherlands $)=175$, sugar beet pulp $=150$, palm kernel flakes $=100$, palm oil $=50$, molasses $=40$, linseed $=28$, rumen-protected rapeseed meal (Mervobest, NuScience) $=25, \mathrm{CaCO} 3=14$, trace mineral and vitamin mix $=8.0, \mathrm{NaCl}=5, \mathrm{MgO}=0.5$, and $\mathrm{TiO} 2=5.0 . \mathrm{DCAD}=$ $152 \mathrm{mEq} / \mathrm{kg}$ of DM.

${ }^{4} \mathrm{GE}=$ gross energy.

${ }^{5}$ Not determined.

${ }^{6}$ Dutch feed unit lactation (van Es, 1978).

${ }^{7}$ Intestinal digestible protein (van Duinkerken et al., 2011).

${ }^{8}$ Rumen-degraded protein balance (van Duinkerken et al., 2011). termine the ATTD of nutrients, $\mathrm{TiO}_{2}$ was included in the concentrate $(5 \mathrm{~g} / \mathrm{kg}$ of DM) as an external marker. The concentrate was in meal form and produced by Research Diet Services (RDS BV, Wijk bij Duurstede, the Netherlands) in a single batch. The diet was formulated to meet 98 and $91 \%$ of $\mathrm{NE}_{\mathrm{L}}$ (VEM; Dutch feed unit lactation; Van Es, 1978) and intestinal digestible protein requirements (van Duinkerken et al., 2011), respectively, for cows consuming $19.0 \mathrm{~kg}$ of $\mathrm{DM} / \mathrm{d}$ and producing $35 \mathrm{~kg} / \mathrm{d}$ of milk containing $4.0 \%$ fat and $3.5 \%$ protein.

Cows were fed ad libitum for the first $10 \mathrm{~d}$ of the 19-d adaptation period. Intake during the final $5 \mathrm{~d}$ of this $10-\mathrm{d}$ ad libitum intake period was used to calculate a $5 \%$ daily intake restriction for individual cows. From d 11 onward, cows were fed this fixed amount for the remainder of the adaptation and experimental periods. Fresh feed was allocated twice daily at 0500 and $1530 \mathrm{~h}$ by manually mixing the roughage and concentrate portions into a TMR for individual cows. The roughage portion (i.e., grass silage + water) of the diet was mixed 3 times weekly using a self-propelled mixer wagon (Strautmann Verti-Mix 500, Bad Laer, Germany) equipped with a cutter loader system and an electronic weighing scale, and fed directly after preparation or stored in a cooling unit at $6^{\circ} \mathrm{C}$ to be used for future feedings for a maximum of $2 \mathrm{~d}$. Before providing fresh feed, feed refusals were collected and weighed to determine daily feed intake. For an 85.5-h period over d 2 to d 6 of each experimental period $(1530 \mathrm{~h}$ on d 2 until $0500 \mathrm{~h}$ on $\mathrm{d} 6$ ), cows were fed using an automated feeding system that dispensed equal portions of feed every $2 \mathrm{~h}$ to promote metabolic steady-state conditions in preparation for the blood sampling protocol that will be described. Cows had individual and free access to clean drinking water throughout the entire experiment.

\section{Abomasal Infusions}

Infusion lines were placed in the abomasum via the rumen cannula $2 \mathrm{~d}$ before the first experimental period and were checked twice daily for patency and position. 
The infusion device was constructed from $200 \mathrm{~cm}$ of braided polyvinyl chloride hose attached to the rumen cannula plug at the proximal end and a flexible disk (equipped with holes to allow digesta passage) at the distal end to secure its placement through the sulcus omasi. The flexible disk was $12 \mathrm{~cm}$ in diameter and made of plastisol (Bar Diamond Inc., Parma, ID). For the treatments containing no ground corn (see subsequent description), the infusion lines (Tygon S3 E-3603, 3.2 $\mathrm{mm}$ internal diameter, $6.4 \mathrm{~mm}$ outer diameter; VWR, Amsterdam, the Netherlands) were connected between the treatment solutions and the multichannel peristaltic pumps with luer-to-tubing connectors (Sigma-Aldrich, St. Louis, MO) and subsequently inserted and secured into the braided polyvinyl chloride hose feeding into the rumen cannula. For the treatments containing ground corn (see subsequent description), infusion lines with a larger diameter (Tygon S3 E-3603, $4.8 \mathrm{~mm}$ internal diameter, $8.0 \mathrm{~mm}$ outer diameter; VWR) were used and connected in the same way as previously described for the treatments without ground corn. Treatments containing ground corn were maintained in suspension by continuous stirring.

Infusion treatments were (1) no ground corn, no $\mathrm{NH}_{4} \mathrm{Cl}$ (DCAD value basal TMR + infusion of $184 \mathrm{mEq} / \mathrm{kg}$ of $\mathrm{DM}$ ); (2) no ground corn, $2.5 \mathrm{~mol}$ of $\mathrm{NH}_{4} \mathrm{Cl} / \mathrm{d}$ (DCAD value basal TMR + infusion of $60 \mathrm{mEq} / \mathrm{kg}$ of $\mathrm{DM}$ ); (3) no ground corn, $5.0 \mathrm{~mol}$ of $\mathrm{NH}_{4} \mathrm{Cl} / \mathrm{d}$ (DCAD value basal TMR + infusion of $-65 \mathrm{mEq} / \mathrm{kg}$ of DM); (4) 3.0 $\mathrm{kg}$ of ground corn/d, no $\mathrm{NH}_{4} \mathrm{Cl}$ (DCAD value basal TMR + infusion of $212 \mathrm{mEq} / \mathrm{kg}$ of DM); (5) $3.0 \mathrm{~kg}$ of ground corn/d $+2.5 \mathrm{~mol}$ of $\mathrm{NH}_{4} \mathrm{Cl} / \mathrm{d}$ (DCAD value basal TMR + infusion of $99 \mathrm{mEq} / \mathrm{kg}$ of DM); and (6) $3.0 \mathrm{~kg}$ of ground corn $/ \mathrm{d}+5.0 \mathrm{~mol}$ of $\mathrm{NH}_{4} \mathrm{Cl} / \mathrm{d}(\mathrm{DCAD}$ value basal TMR + infusion of $-10 \mathrm{mEq} / \mathrm{kg}$ of $\mathrm{DM}$ ). The DCAD value was calculated based on the equation described by CVB (2018) and the reported Na, K, $\mathrm{Cl}$, and $\mathrm{S}$ values for each separate dietary ingredient. The treatments were administered in 20-L batches that were replenished daily and infused at a rate ranging from 841 to $969 \mathrm{~g} / \mathrm{h}$ (Table 2) to facilitate $120 \mathrm{~h}$ of continuous infusion $(0900 \mathrm{~h}$ on d 1 until $0900 \mathrm{~h}$ on d 6 of each experimental period; Figure 1). Ground corn was chosen as the source to induce hindgut acidosis for 2 reasons. First, in common practice, ground corn is one of the major starch sources fed to dairy cattle in early lactation. Second, ground corn supplies more rumen-resistant starch flowing into the intestine compared with wheat and barley. The ground corn was manipulated (performed by Heme N.V., Waddinxveen, the Netherlands) to represent the rumen-resistant fraction of ground corn. First, the ground corn (Cargill, Velddriel, the Netherlands) was sieved over a 1-mm screen. The fine fraction was discarded, because this fraction is assumed to be largely rumen-fermentable. Second, the remaining coarse fraction was ground to pass a $1-\mathrm{mm}$ screen and again sieved over a $0.63-\mathrm{mm}$ screen. After this second step of sieving, the remaining coarse fraction was discarded, and only the fine fraction was used for the infusion treatments. The last 2 steps (i.e., sieving + discarding the coarse fraction) were performed to minimize obstruction in the infusion lines as well as to aid in keeping the infusion treatment in solution. The differences in DCAD values were achieved by manipulation of dietary $\mathrm{Cl}$ via the addition of different amounts of $\mathrm{NH}_{4} \mathrm{Cl}$ to the infusion treatments (Table 2).

\section{Climate Respiration Chambers}

The cows were housed in CRC for the experimental periods to determine gaseous exchange, energy and $\mathrm{N}$ balance, and ATTD of nutrients. Detailed descriptions of the CRC design and gas measurements are reported by Heetkamp et al. (2015) and van Gastelen et al. (2015). Briefly, the relative humidity and temperature in each $\mathrm{CRC}$ compartment ( area $=11.8 \mathrm{~m}^{2}$, volume $=34.5 \mathrm{~m}^{3}$ ) were maintained at $80 \%$ and $10^{\circ} \mathrm{C}$, respectively. The CRC were equipped with thin walls with windows to allow audio-visual contact between cows, to minimize the effects of social isolation on cow behavior and performance. Cows were exposed to $16.5 \mathrm{~h}$ of light per d (0500 to $2130 \mathrm{~h})$.

Gas concentrations and ventilation rates were corrected for pressure, temperature, and relative humidity to obtain standard temperature pressure dew point volumes of inlet and exhaust air. The inlet and exhaust air of each CRC were sampled as described by van Gastelen et al. (2015), with a second gas analyzer used for the additional 2 CRC compartments, as described by Nichols et al. (2019). Production of $\mathrm{CO}_{2}$ and $\mathrm{CH}_{4}$ and consumption of $\mathrm{O}_{2}$ were calculated from the difference between inlet and exhaust gas volumes. Calibration gases were sampled once daily for gas analysis instead of the inlet air. The analyzed and actual values of these calibration gases were used to correct the measured gas concentrations from the inlet air and exhaust air of the 6 CRC compartments. Before the cows entered the CRC and after the final experimental period, each CRC was checked by releasing known amounts of $\mathrm{CO}_{2}$ and comparing these values with the data from the gas analysis system to determine $\mathrm{CO}_{2}$ recovery. The average recovery of $\mathrm{CO}_{2}$ was $99.7 \%$ (ranging between 98.5 and $101.7 \%$ for individual compartments). Gas measurements during time points when staff entered the CRC compartments (maximum 30 min for milking, feeding, and checking the abomasal infusion lines) were discarded from the data analysis. Production of $\mathrm{CO}_{2}$ and $\mathrm{CH}_{4}$ and consumption of $\mathrm{O}_{2}$ was assumed to be 


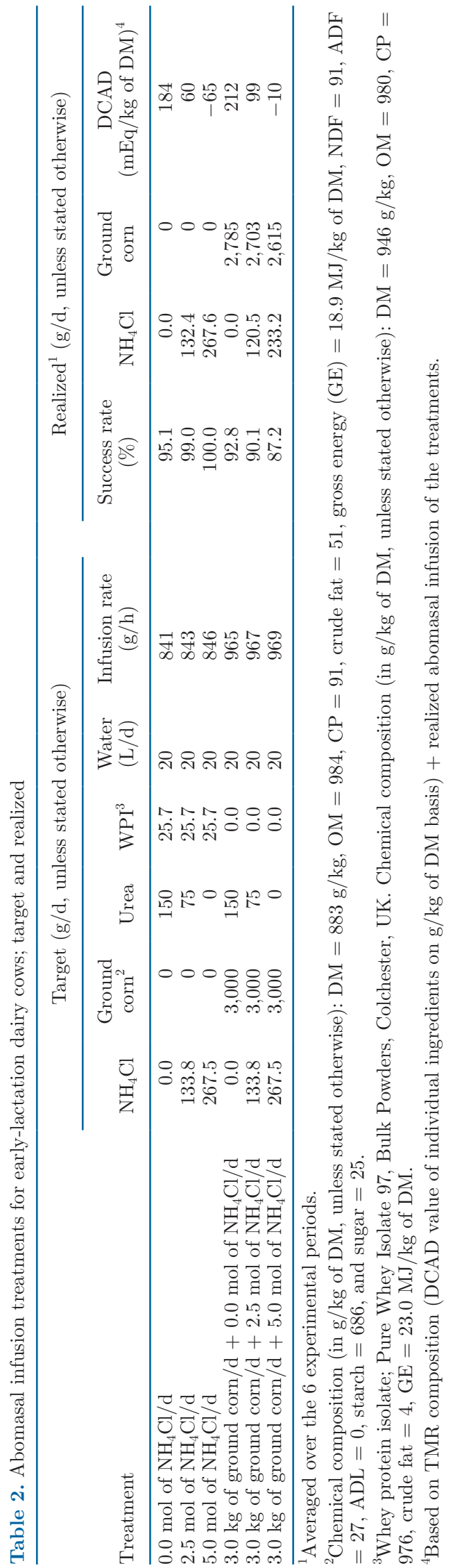

linear between the last data point before opening and the first data point after closing the CRC.

\section{Sample Collection and Measurements}

Cows were milked twice daily at 0500 and $1530 \mathrm{~h}$ during the adaptation and experimental periods. Milk weight was recorded at each milking. Milk samples were collected at each milking during the balance period (6 milkings; Figure 1) into tubes containing sodium azide $(5 \mu \mathrm{L})$ for preservation, and were stored no longer than $4 \mathrm{~d}$ at $4^{\circ} \mathrm{C}$ until analysis. An additional milk sample (5 $\mathrm{g} / \mathrm{kg}$ of milk) was collected at each milking during the balance period ( 6 milkings), and stored at $-20^{\circ} \mathrm{C}$ until energy and $\mathrm{N}$ analyses.

Samples of rumen fluid, feces, and urine were collected immediately before each milking event during the balance period $(\mathrm{n}=6)$. Rumen fluid samples $(\sim 200$ $\mathrm{mL}$ ) were obtained as described by van Zijderveld et al. (2011), and were composed of equal volumes collected from the front and middle of the ventral sac and from the cranial sac of the rumen. Fecal samples were collected by rectal grab sampling. Urine samples were collected by stimulating the dairy cows to urinate by rubbing the perineum using a vertical movement. After collection, feces, urine, and rumen fluid were thoroughly mixed, and their $\mathrm{pH}$ was immediately measured using an electronic pH meter (HI9024C, Hanna Instruments, IJsselstein, the Netherlands). Urine samples were subsequently discarded. Subsamples of feces $(\sim 100 \mathrm{~g})$ and rumen fluid $(600 \mu \mathrm{L})$ were collected and acidified with an equal volume of orthophosphoric acid $(0.85 \mathrm{mg} / \mathrm{L})$ containing $19.68 \mathrm{~m} M$ isocaproic acid as internal standard. Samples were subsequently frozen $\left(-20^{\circ} \mathrm{C}\right)$ until VFA analysis.

Samples of grass silage and the concentrate were collected 3 times weekly during feed preparation. These samples were subsequently pooled per experimental period and stored at $-20^{\circ} \mathrm{C}$ until analysis. During balance periods in the $\mathrm{CRC}$, feed residues were collected twice daily (0500 h and $1530 \mathrm{~h}$ ), weighed, and stored at $4^{\circ} \mathrm{C}$. At the end of each experimental period, daily orts were pooled per cow, mixed, subsampled, and stored at $-20^{\circ} \mathrm{C}$ until analysis.

Measurements of $\mathrm{CH}_{4}$ and $\mathrm{CO}_{2}$ production and $\mathrm{O}_{2}$ consumption were based on data recorded from d 4 $(0800 \mathrm{~h})$ through d $6(0800 \mathrm{~h})$ of each experimental period (gaseous exchange; Figure 1), whereas energy and $\mathrm{N}$ balance and the ATTD of nutrients were based on manure and feces collection from d 3 (1000 h) through d 6 (0900 h; balance period; Figure 1). The end of the balance period corresponded with the end of the 120-h infusion period. Cows were weighed at the start and at the end of each balance period. Each CRC 
compartment was cleaned at $0900 \mathrm{~h}$ on d 3 (taking approximately $60 \mathrm{~min}$ ) to remove manure collected from the end of the previous period, to facilitate a fresh total collection period. The feces and urine produced during the balance period were quantitatively collected as manure (by cleaning each CRC compartment), weighed, mixed, subsampled, and stored at $-20^{\circ} \mathrm{C}$ until analysis. To quantify contribution of $\mathrm{N}$ from volatilized ammonia appearing from excreted and mixed feces and urine, samples were collected of condensed water from the chamber heat exchanger of each CRC compartment and from a $25 \%$ sulfuric acid solution (wt/wt) in which aerial ammonia in outflowing air was trapped. These samples were stored at $4^{\circ} \mathrm{C}$ until analysis. During the balance period, rectal grab samples of feces $(\sim 300 \mathrm{~g})$ were collected twice daily at $0500 \mathrm{~h}$ and $1530 \mathrm{~h}(6$ samples in total) and immediately pooled into a composite sample by cow, which was stored at $-20^{\circ} \mathrm{C}$ until analysis.

On d 4 and 5 of each experimental period, blood samples were collected from the coccygeal vessels into $10-\mathrm{mL}$ sodium heparin and potassium EDTA vacutainers (Becton Dickinson, Rutherford, NJ) at 0800, 1000, 1200, and $1400 \mathrm{~h}$. At each sampling moment, a subsample was collected immediately from the heparin vacutainer and analyzed by a hand-held VetScan i-STAT 1 analyzer (Abaxis Inc., Union City, CA) using disposable CG8+ cartridges (Abbott, Princeton, NJ). Immediately thereafter, both the heparin and potassium EDTA vacutainers were placed in ice and centrifuged at $5,000 \times g$ for $15 \mathrm{~min}$ at room temperature, aliquoted, and stored at $-20^{\circ} \mathrm{C}$ until further analysis (i.e., each time point was analyzed separately).

\section{Analytical Procedures}

Samples of grass silage, concentrate, feed residues, manure, and feces were thawed at room temperature, freeze-dried until a constant weight was reached, and ground to pass a 1-mm screen using a cross-beater mill for the grass silage (Peppink 100AN, Olst, the Netherlands) and an ultra-centrifugal mill for all other samples (Retsch ZM200, Retsch GmbH, Haan, Germany). Wet chemical analyses for $\mathrm{DM}$, ash, $\mathrm{N}, \mathrm{NH}_{3}-\mathrm{N}$, starch, reducing sugars (i.e., all carbohydrates with reducing properties and soluble in $40 \%$ ethanol), crude fat, NDF, $\mathrm{ADF}, \mathrm{ADL}$, and $\mathrm{Ti}$ were performed as described by Nichols et al. (2018). Bomb calorimetry (ISO 9831; International Organization for Standardization, 1998; adiabatic bomb calorimeter, IKA-C700, Janke and Kunkel, Heitersheim, Germany) was used to determine gross energy (GE) content. Crude protein was calculated as $\mathrm{N} \times 6.25$.
Grass silage and the concentrate were analyzed for DM, ash, N, crude fat, starch (concentrate only), sugars, NDF, ADF, ADL, GE, and Ti (concentrate only). Feed residues were analyzed for DM. Manure samples were analyzed for DM, N, and GE. Feces samples were analyzed for DM, ash, N, crude fat, starch, NDF, GE, and Ti. In addition, samples of condensed water and the sulfuric acid solution were analyzed for N. Milk samples from individual milking events were analyzed for fat, protein, lactose, BHB, and acetone content by midinfrared spectroscopy (ISO 9622; International Organization for Standardization, 2013; VVB, Doetinchem, the Netherlands). Pooled milk samples were analyzed for GE and $\mathrm{N}$ in fresh material as previously described.

For determination of VFA, the rumen fluid samples and fecal samples were analyzed as described by van Gastelen et al. (2015). Briefly, samples were thawed and centrifuged for $5 \mathrm{~min}$ at $14,000 \times \mathrm{g}$ at room temperature. The clear supernatant $(1 \mu \mathrm{L})$ was injected onto a gas chromatograph (Fisons HRGC Mega 2, CE Instruments, Milan, Italy) with a split/splitless injector operated in split mode (split ratio 1:10), at a temperature of $225^{\circ} \mathrm{C}$, using a capillary column (EC-1000, Alltech, Deerfield, IL; $30 \mathrm{~m}, 0.53 \mathrm{~mm}$ internal diameter, $1 \mu \mathrm{m}$ film thickness) and helium as carrier gas, and fitted to a flame ionization detector. Identification and quantification were conducted with a chemical standard solution $(0.85 \mathrm{mg} / \mathrm{L}$ orthophosphoric acid), including an internal standard (19.681 $\mathrm{m} M$ isocaproic acid) for correction.

Blood plasma was analyzed by the Utrecht University Veterinary Diagnostic Laboratory (Utrecht, the Netherlands) for urea, insulin, triglycerides, BHB, nonesterified fatty acids (NEFA), IGF-1, albumin, serum amyloid A (SAA), and haptoglobin. Plasma NEFA, $\mathrm{BHB}$, insulin, and urea were analyzed as described by van Knegsel et al. (2007). Plasma IGF-1 (cat. no. L2KIGF, Siemens Healthineers, Erlangen, Germany) and SAA (Phase SAA assay, cat. no. TP-802, Tridelta Development Limited, Maynooth, Ireland) were analyzed using the advanced immunoassay Immulite 2000 system (Siemens, The Hague, the Netherlands). Plasma haptoglobin (Phase Haptoglobin Assay, cat. no. TP801, Tridelta Development Limited), albumin (cat. no. OSR6102, Beckman Coulter Inc., Brea, CA), and triglycerides (cat. no. OSR60118, Beckman Coulter Inc.) were analyzed using the clinical chemistry analyzer Olympus AU-860 (Beckman Coulter Inc.).

\section{Calculations and Statistical Analysis}

Reported values for nutrient content of the TMR were calculated from ration composition and analyzed 
values obtained for the grass silage and concentrate. The $\mathrm{NE}_{\mathrm{L}}$ was calculated with the VEM (Dutch feed unit lactation) system according to Van Es (1978). For the grass silage, digestible protein, rumen-degradable protein balance (see Table 1), and $\mathrm{NE}_{\mathrm{L}}$ were calculated based on the chemical composition as obtained by near-infrared spectroscopy analysis (Eurofins Agro, Wageningen, the Netherlands). For the concentrate, digestible protein, rumen-degradable protein, and $\mathrm{NE}_{\mathrm{L}}$ were calculated based on table values for composition of the ingredients (CVB, 2018).

Fat- and protein-corrected milk yield (FPCM; $\mathrm{kg} / \mathrm{d})$ was calculated as $(0.337+0.116 \times$ fat $\%+0.06 \times$ protein $\%) \times$ milk yield (CVB, 2018). Heat production $(\mathrm{kJ} / \mathrm{d})$ was calculated as $16.175 \times \mathrm{VO}_{2}(\mathrm{~L} / \mathrm{d})+5.021$ $\times \mathrm{VCO}_{2}(\mathrm{~L} / \mathrm{d})$, where $\mathrm{VO}_{2}$ and $\mathrm{VCO}_{2}$ are volumes of $\mathrm{O}_{2}$ consumed and $\mathrm{CO}_{2}$ produced, respectively (Gerrits et al., 2015). The ATTD of nutrients was calculated taking into account nutrient inflow with the TMR as well as the abomasal treatment infusions.

All variables related to feed intake, milk yield, and milk composition were averaged over the 3 -d balance period. Whole-blood constituents measured with the iSTAT as well as the VFA and pH of rumen fluid, feces, and urine ( $\mathrm{pH}$ only) were averaged over the analyzed sampling times. The variables related to energy and $\mathrm{N}$ balance were expressed per kilogram of metabolic BW per day. Cow was considered the experimental unit for all variables. Data were analyzed using the MIXED procedure in SAS (version 9.4, SAS Institute Inc., Cary, $\mathrm{NC}$ ). The model contained main effects and interaction effects of infusion treatment factors $\left(\mathrm{NH}_{4} \mathrm{Cl}\right.$ and ground corn) as fixed effects, and cow and period as random effects. Differences were considered significant at $P \leq$ 0.050 and tendencies at $0.050<P \leq 0.100$. Multiple comparisons between treatment means were made using the Tukey-Kramer method when an $\mathrm{NH}_{4} \mathrm{Cl}$ effect or ground corn $\times \mathrm{NH}_{4} \mathrm{Cl}$ interaction [i.e., between 2 levels of ground corn $(0.0$ or $3.0 \mathrm{~kg} / \mathrm{d})$ and 3 levels of $\mathrm{NH}_{4} \mathrm{Cl}$ $(0.0,2.5$, or $5.0 \mathrm{~mol} / \mathrm{d})]$ was detected at $P \leq 0.050$. Treatment arrangement within the Latin square was balanced for first-order carryover effects in subsequent periods (Williams, 1949), where each treatment immediately preceded and followed every other treatment exactly once in each square. We assessed for carryover effects between periods by testing for an effect of the previous treatment in the ANOVA.

\section{RESULTS}

\section{Nutrient Intake and Digestibility}

Nutrient intake and ATTD of nutrients were not affected by ground corn $\times \mathrm{NH}_{4} \mathrm{Cl}$ interactions (Table 3).
Infusion of ground corn increased $(P \leq 0.025)$ the total intake (TMR + infusion) of DM, OM, fat, starch, and $\mathrm{GE}$, and tended to increase the intake of digestible OM $(P=0.064)$, relative to no infusion of ground corn. Ground corn infusion decreased $(P \leq 0.002)$ the ATTD of DM, OM, CP, GE, and NDF, and increased $(P<$ 0.001) the ATTD of starch compared with no infusion of ground corn. Regardless of ground corn inclusion, $5.0 \mathrm{~mol}$ of $\mathrm{NH}_{4} \mathrm{Cl} / \mathrm{d}$ decreased $(P \leq 0.048)$ the total intake of $\mathrm{CP}$, digestible NDF, and starch relative to no $\mathrm{NH}_{4} \mathrm{Cl}$ infusion, with no difference observed between 0.0 and $2.5 \mathrm{~mol}$ of $\mathrm{NH}_{4} \mathrm{Cl} / \mathrm{d}$ and between 2.5 and 5.0 mol of $\mathrm{NH}_{4} \mathrm{Cl} / \mathrm{d}$. Compared with no $\mathrm{NH}_{4} \mathrm{Cl}$ infusion, both 2.5 and $5.0 \mathrm{~mol}$ of $\mathrm{NH}_{4} \mathrm{Cl} / \mathrm{d}$ tended $(P \leq 0.094)$ to decrease the total intake of OM, digestible OM, crude fat, GE, NDF, ADF, ADL, and sugar. Infusion of 5.0 mol of $\mathrm{NH}_{4} \mathrm{Cl} / \mathrm{d}$ increased $(P=0.009)$ the ATTD of CP relative to both 0.0 and $2.5 \mathrm{~mol}$ of $\mathrm{NH}_{4} \mathrm{Cl} / \mathrm{d}$, with no difference between 0.0 and $2.5 \mathrm{~mol}$ of $\mathrm{NH}_{4} \mathrm{Cl} / \mathrm{d}$. Additionally, $5.0 \mathrm{~mol}$ of $\mathrm{NH}_{4} \mathrm{Cl} / \mathrm{d}$ increased $(P<0.029)$ the ATTD of fat and starch relative to no $\mathrm{NH}_{4} \mathrm{Cl}$ infusion, with no difference between 0.0 and $2.5 \mathrm{~mol}$ of $\mathrm{NH}_{4} \mathrm{Cl} / \mathrm{d}$ and between 2.5 and $5.0 \mathrm{~mol}$ of $\mathrm{NH}_{4} \mathrm{Cl} / \mathrm{d}$.

\section{Lactation Performance}

Only milk lactose content tended to be affected by a ground corn $\times \mathrm{NH}_{4} \mathrm{Cl}$ interaction (Table 4), where lactose content decreased as $\mathrm{NH}_{4} \mathrm{Cl}$ increased from 0.0 to $5.0 \mathrm{~mol} / \mathrm{d}$, but the decrease tended to be less when ground corn was included in the infusion $(P=0.075)$. Infusion of ground corn increased $(P \leq 0.041)$ milk yield, lactose content and yield, and protein yield, tended to increase $(P=0.093)$ fat- and protein-corrected milk yield, and decreased $(P \leq 0.001)$ content of fat, BHB, and acetone relative to no infusion of ground corn. Regardless of ground corn inclusion, milk lactose content decreased $(P<0.001)$ with increasing level of $\mathrm{NH}_{4} \mathrm{Cl}$ infusion. No other lactation performance variable was affected by $\mathrm{NH}_{4} \mathrm{Cl}$.

\section{Blood Constituents}

Concerning the i-STAT measurements, whole-blood $\mathrm{pH}$, base excess, $\mathrm{HCO}_{3}$, total $\mathrm{CO}_{2}$, and ionized calcium were affected by ground corn $\times \mathrm{NH}_{4} \mathrm{Cl}$ interactions $(P$ $\leq 0.037$; Table 5). In the absence of ground corn, blood $\mathrm{pH}$, base excess, $\mathrm{HCO}_{3}$, and total $\mathrm{CO}_{2}$ were lower for $5.0 \mathrm{~mol}$ of $\mathrm{NH}_{4} \mathrm{Cl} / \mathrm{d}$ compared with 0.0 and $2.5 \mathrm{~mol}$ of $\mathrm{NH}_{4} \mathrm{Cl} / \mathrm{d}$, with no difference in these blood constituents between 0.0 and $2.5 \mathrm{~mol}$ of $\mathrm{NH}_{4} \mathrm{Cl} / \mathrm{d}$. By contrast, in the presence of ground corn, blood $\mathrm{pH}$, base excess, $\mathrm{HCO}_{3}$, and total $\mathrm{CO}_{2}$ were lower with both 2.5 and $5.0 \mathrm{~mol}$ of $\mathrm{NH}_{4} \mathrm{Cl} / \mathrm{d}$ compared with no $\mathrm{NH}_{4} \mathrm{Cl}$ infusion, 
Table 3. Nutrient intake (TMR + abomasal infusion) and apparent total-tract digestibility of nutrients of early-lactation dairy cows abomasally infused with ground corn and $\mathrm{NH}_{4} \mathrm{Cl}$

\begin{tabular}{|c|c|c|c|c|c|c|c|c|c|}
\hline \multirow[b]{2}{*}{ Item } & \multicolumn{2}{|c|}{ Ground corn $(\mathrm{kg} / \mathrm{d})$} & \multicolumn{3}{|c|}{$\mathrm{NH}_{4} \mathrm{Cl}(\mathrm{mol} / \mathrm{d})$} & \multirow[b]{2}{*}{ SEM } & \multicolumn{3}{|c|}{$P$-value } \\
\hline & 0.0 & 3.0 & 0.0 & 2.5 & 5.0 & & $\begin{array}{l}\text { Ground } \\
\text { corn }\end{array}$ & $\mathrm{NH}_{4} \mathrm{Cl}$ & $\begin{array}{l}\text { Ground corn } \\
\times \mathrm{NH}_{4} \mathrm{Cl}^{1}\end{array}$ \\
\hline \multicolumn{10}{|c|}{$\begin{array}{l}\text { Nutrient intake (TMR + abomasal } \\
\text { infusions, } \mathrm{kg} / \mathrm{d} \text { unless stated } \\
\text { otherwise) }\end{array}$} \\
\hline DM & 13.0 & 14.5 & 14.4 & 14.0 & 12.8 & 0.60 & 0.025 & 0.103 & 0.371 \\
\hline $\mathrm{CP}$ & 2.71 & 2.71 & $2.86^{\mathrm{a}}$ & $2.75^{\mathrm{ab}}$ & $2.52^{\mathrm{b}}$ & 0.119 & 0.960 & 0.048 & 0.432 \\
\hline Crude fat & 0.70 & 0.78 & 0.78 & 0.75 & 0.68 & 0.031 & 0.023 & 0.067 & 0.316 \\
\hline Gross energy $(\mathrm{MJ} / \mathrm{d})$ & 245.2 & 273.4 & 273.6 & 263.8 & 240.6 & 11.51 & 0.021 & 0.078 & 0.362 \\
\hline NDF & 5.77 & 5.60 & 6.01 & 5.79 & 5.26 & 0.270 & 0.537 & 0.094 & 0.354 \\
\hline Digestible NDF & 4.19 & 3.90 & $4.29^{\mathrm{a}}$ & $4.14^{\mathrm{ab}}$ & $3.70^{\mathrm{b}}$ & 0.199 & 0.121 & 0.041 & 0.203 \\
\hline $\mathrm{ADF}$ & 3.28 & 3.13 & 3.38 & 3.27 & 2.96 & 0.159 & 0.316 & 0.086 & 0.299 \\
\hline $\mathrm{ADL}$ & 0.19 & 0.18 & 0.19 & 0.19 & 0.17 & 0.010 & 0.165 & 0.079 & 0.248 \\
\hline $\mathrm{CP}$ & 68.5 & 62.8 & $64.4^{\mathrm{a}}$ & $64.9^{\mathrm{a}}$ & $67.6^{\mathrm{b}}$ & 1.03 & $<0.001$ & 0.009 & 0.453 \\
\hline Crude fat & 70.4 & 70.4 & $68.9^{\mathrm{a}}$ & $70.0^{\mathrm{ab}}$ & $72.4^{\mathrm{b}}$ & 1.47 & 0.967 & 0.006 & 0.551 \\
\hline Gross energy & 70.2 & 67.3 & 68.2 & 68.2 & 69.7 & 0.80 & $<0.001$ & 0.132 & 0.469 \\
\hline NDF & 72.6 & 69.7 & 71.5 & 71.1 & 70.8 & 0.86 & 0.002 & 0.816 & 0.623 \\
\hline Starch & 93.6 & 95.0 & $93.6^{\mathrm{a}}$ & $94.4^{\mathrm{ab}}$ & $94.9^{\mathrm{b}}$ & 0.44 & $<0.001$ & 0.029 & 0.466 \\
\hline
\end{tabular}

${ }_{\mathrm{a}, \mathrm{b}}$ Values with different superscripts indicate a significant difference $(P<0.05)$ between $0.0,2.5$, and $5.0 \mathrm{~mol}$ of $\mathrm{NH} \mathrm{Cl}_{4} / \mathrm{d}$.

${ }^{1}$ Interaction between 2 levels of ground corn $(0.0$ and $3.0 \mathrm{~kg} / \mathrm{d})$ and 3 levels of $\mathrm{NH}_{4} \mathrm{Cl}(0.0,2.5$, and $5.0 \mathrm{~mol} / \mathrm{d})$.

with no difference between 2.5 and $5.0 \mathrm{~mol}$ of $\mathrm{NH}_{4} \mathrm{Cl} / \mathrm{d}$. For ionized calcium the same pattern of treatment effects was observed, but in the opposite direction. In the absence of ground corn, ionized calcium was higher with $5.0 \mathrm{~mol}$ of $\mathrm{NH}_{4} \mathrm{Cl} / \mathrm{d}$ compared with both 0.0 and $2.5 \mathrm{~mol}$ of $\mathrm{NH}_{4} \mathrm{Cl} / \mathrm{d}$, and in presence of ground corn ionized calcium was higher for both 2.5 and $5.0 \mathrm{~mol}$ of $\mathrm{NH}_{4} \mathrm{Cl} / \mathrm{d}$ compared with no $\mathrm{NH}_{4} \mathrm{Cl}$ infusion (with no difference between 2.5 and $5.0 \mathrm{~mol}$ of $\mathrm{NH}_{4} \mathrm{Cl} / \mathrm{d}$ ). Infusion of ground corn increased $(P \leq 0.011)$ wholeblood concentration of sodium and glucose relative to no ground corn infusion. Regardless of ground corn inclusion, increasing infusion of $\mathrm{NH}_{4} \mathrm{Cl}$ decreased $(P<$ 0.001) partial pressure of $\mathrm{CO}_{2}$. Additionally, $2.5 \mathrm{~mol}$ of

Table 4. Milk production and composition of early-lactation dairy cows abomasally infused with ground corn and $\mathrm{NH}_{4} \mathrm{Cl}$

\begin{tabular}{|c|c|c|c|c|c|c|c|c|c|}
\hline \multirow[b]{2}{*}{ Item } & \multicolumn{2}{|c|}{ Ground corn $(\mathrm{kg} / \mathrm{d})$} & \multicolumn{3}{|c|}{$\mathrm{NH}_{4} \mathrm{Cl}(\mathrm{mol} / \mathrm{d})$} & \multirow[b]{2}{*}{ SEM } & \multicolumn{3}{|c|}{$P$-value } \\
\hline & 0.0 & 3.0 & 0.0 & 2.5 & 5.0 & & $\begin{array}{l}\text { Ground } \\
\text { corn }\end{array}$ & $\mathrm{NH}_{4} \mathrm{Cl}$ & $\begin{array}{l}\text { Ground corn } \\
\quad \times \mathrm{NH}_{4} \mathrm{Cl}^{1}\end{array}$ \\
\hline Milk yield (kg/d) & 20.0 & 22.8 & 21.2 & 22.2 & 20.7 & 1.37 & 0.002 & 0.282 & 0.902 \\
\hline $\operatorname{FPCM}^{2}(\mathrm{~kg} / \mathrm{d})$ & 21.2 & 22.5 & 21.9 & 22.6 & 21.0 & 0.95 & 0.093 & 0.190 & 0.989 \\
\hline $\begin{array}{l}\text { Feed efficiency ( } \mathrm{kg} \text { of } \\
\mathrm{FPCM} / \mathrm{kg} \text { of DMI) }\end{array}$ & 1.66 & 1.59 & 1.54 & 1.62 & 1.72 & 0.090 & 0.306 & 0.181 & 0.219 \\
\hline Fat content (g/100 g) & 4.71 & 4.15 & 4.51 & 4.41 & 4.37 & 0.216 & $<0.001$ & 0.428 & 0.540 \\
\hline Protein content (g/100 g) & 3.02 & 2.99 & 3.02 & 3.02 & 2.98 & 0.123 & 0.307 & 0.636 & 0.843 \\
\hline Lactose content $(\mathrm{g} / 100 \mathrm{~g})$ & 4.34 & 4.41 & $4.48^{\mathrm{a}}$ & $4.38^{\mathrm{b}}$ & $4.27^{\mathrm{c}}$ & 0.106 & 0.041 & $<0.001$ & 0.075 \\
\hline Fat yield $(\mathrm{g} / \mathrm{d})$ & 936 & 928 & 944 & 963 & 890 & 41.4 & 0.805 & 0.184 & 0.913 \\
\hline Protein yield (g/d) & 600 & 673 & 638 & 658 & 613 & 19.9 & $<0.001$ & 0.170 & 0.993 \\
\hline Lactose yield (g/d) & 871 & 1,000 & 952 & 972 & 882 & 59.7 & 0.001 & 0.110 & 0.996 \\
\hline $\mathrm{BHB}(\mathrm{mmol} / \mathrm{L})$ & 0.181 & 0.120 & 0.154 & 0.151 & 0.148 & 0.0143 & $<0.001$ & 0.811 & 0.588 \\
\hline Acetone $(\mathrm{mmol} / \mathrm{L})$ & 0.318 & 0.218 & 0.268 & 0.269 & 0.267 & 0.0203 & $<0.001$ & 0.994 & 0.882 \\
\hline
\end{tabular}

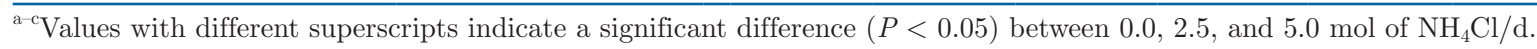

${ }^{1}$ Interaction between 2 levels of ground corn $(0.0$ and $3.0 \mathrm{~kg} / \mathrm{d})$ and 3 levels of $\mathrm{NH}_{4} \mathrm{Cl}(0.0,2.5$, and $5.0 \mathrm{~mol} / \mathrm{d})$.

${ }^{2}$ Fat- and protein-corrected milk $=(0.337+0.116 \times$ fat $\%+0.06 \times$ protein $\%) \times$ milk yield $(\mathrm{kg} / \mathrm{d}) ; \mathrm{CVB}, 2018$. 
Table 5. Whole-blood constituents, measured with a VetScan i-STAT 1 analyzer (Abaxis Inc., Union City, CA), of early-lactation dairy cows abomasally infused with ground corn and $\mathrm{NH}_{4} \mathrm{Cl}$

\begin{tabular}{|c|c|c|c|c|c|c|c|c|c|}
\hline \multirow[b]{2}{*}{ Item } & \multicolumn{2}{|c|}{ Ground corn $(\mathrm{kg} / \mathrm{d})$} & \multicolumn{3}{|c|}{$\mathrm{NH}_{4} \mathrm{Cl}(\mathrm{mol} / \mathrm{d})$} & \multirow[b]{2}{*}{ SEM } & \multicolumn{3}{|c|}{$P$-value } \\
\hline & 0.0 & 3.0 & 0.0 & 2.5 & 5.0 & & $\begin{array}{l}\text { Ground } \\
\text { corn }\end{array}$ & $\mathrm{NH}_{4} \mathrm{Cl}$ & $\begin{array}{l}\text { Ground corn } \\
\times \mathrm{NH}_{4} \mathrm{Cl}^{1}\end{array}$ \\
\hline $\mathrm{pCO}_{2}{ }^{3}(\mathrm{~mm} \mathrm{Hg})$ & 42.1 & 42.4 & $46.1^{\mathrm{a}}$ & $42.1^{\mathrm{b}}$ & $38.6^{\mathrm{c}}$ & 1.70 & 0.713 & $<0.001$ & 0.080 \\
\hline $\mathrm{pO}_{2}{ }^{4}(\mathrm{~mm} \mathrm{Hg})$ & 72.6 & 71.9 & 68.7 & 74.8 & 73.2 & 8.58 & 0.916 & 0.753 & 0.404 \\
\hline Base $\operatorname{excess}^{5}(\mathrm{mmol} / \mathrm{L})$ & 2 & 1 & 9 & 1 & -6 & 1.2 & 0.263 & $<0.001$ & 0.013 \\
\hline $\mathrm{sO}_{2}^{8}(\%)$ & 79 & 80 & 79 & 78 & 80 & 3.7 & 0.760 & 0.917 & 0.411 \\
\hline Sodium $(\mathrm{mmol} / \mathrm{L})$ & 138 & 139 & 138 & 138 & 137 & 0.7 & 0.009 & 0.065 & 0.300 \\
\hline Potassium (mmol/L) & 4.7 & 4.7 & $4.6^{\mathrm{a}}$ & $4.8^{\mathrm{b}}$ & $4.7^{\mathrm{ab}}$ & 0.05 & 0.554 & 0.019 & 0.255 \\
\hline Ionized calcium $^{9}(\mathrm{mmol} / \mathrm{L})$ & 1.29 & 1.29 & 1.22 & 1.28 & 1.35 & 0.014 & 0.963 & $<0.001$ & 0.011 \\
\hline Glucose $(\mathrm{mg} / \mathrm{dL})$ & 61 & 64 & $64^{\mathrm{a}}$ & $63^{\mathrm{ab}}$ & $61^{\mathrm{b}}$ & 1.6 & 0.011 & 0.038 & 0.771 \\
\hline Hematocrit $^{10}(\%$ PCV $)$ & 24 & 24 & 24 & 24 & 24 & 0.7 & 0.429 & 0.962 & 0.213 \\
\hline Hemoglobin (g/dL) & 8.20 & 8.12 & 8.16 & 8.16 & 8.17 & 0.242 & 0.474 & 0.998 & 0.247 \\
\hline
\end{tabular}

${ }^{\mathrm{a}-\mathrm{c}}$ Values with different superscripts indicate a significant difference $(P<0.05)$ between $0.0,2.5$, and $5.0 \mathrm{~mol} \mathrm{of} \mathrm{NH} \mathrm{m}_{4} \mathrm{Cl} / \mathrm{d}$.

${ }^{1}$ Interaction between 2 levels of ground corn $(0.0$ or $3.0 \mathrm{~kg} / \mathrm{d})$ and 3 levels of $\mathrm{NH}_{4} \mathrm{Cl}(0.0,2.5$, or $5.0 \mathrm{~mol} / \mathrm{d})$. If a significant ground corn $\times \mathrm{NH}_{4} \mathrm{Cl}$ interaction was found, a different superscript $(\mathrm{k}-\mathrm{n})$ in the footnote of that particular variable indicates a significant difference $(P<0.05)$.

${ }^{2}$ Ground corn $\times \mathrm{NH}_{4} \mathrm{Cl}$ interaction: $0.0 \mathrm{~mol}$ of $\mathrm{NH}_{4} \mathrm{Cl} / \mathrm{d}$ with $0.0 \mathrm{~kg}$ of starch $/ \mathrm{d}=7.50^{\mathrm{k}} ; 2.5 \mathrm{~mol}$ of NH $\mathrm{Nl}_{4} / \mathrm{d}$ with $0.0 \mathrm{~kg}$ of starch $/ \mathrm{d}=7.44^{\mathrm{kl}}$; $5.0 \mathrm{~mol}$ of $\mathrm{NH}_{4} \mathrm{Cl} / \mathrm{d}$ with $0.0 \mathrm{~kg}$ of starch $/ \mathrm{d}=7.30^{\mathrm{m}} ; 0.0 \mathrm{~mol}$ of $\mathrm{NH}_{4} \mathrm{Cl} / \mathrm{d}$ with $3.0 \mathrm{~kg}$ of starch $/ \mathrm{d}=7.46^{\mathrm{k}} ; 2.5 \mathrm{~mol}$ of NH $\mathrm{NH}_{4} \mathrm{Cl} / \mathrm{d}$ with $3.0 \mathrm{~kg}$ of starch $/ \mathrm{d}=7.36^{\mathrm{lm}} ; 5.0 \mathrm{~mol}$ of $\mathrm{NH}_{4} \mathrm{Cl} / \mathrm{d}$ with $3.0 \mathrm{~kg}$ of $\operatorname{starch} / \mathrm{d}=7.34^{\mathrm{m}}$.

${ }^{3}$ Partial pressure of $\mathrm{CO}_{2}$.

${ }^{4}$ Partial pressure of $\mathrm{O}_{2}$.

${ }^{5}$ Defined as the $\mathrm{mEq}$ of acid or base that must be added to $1 \mathrm{~L}$ of blood to restore the pH to 7.40 at $37^{\circ} \mathrm{C}$ and at a $P C \mathrm{O}_{2}$ of $40 \mathrm{~mm} \mathrm{Hg}(\mathrm{Corey}$, 2003). Ground corn $\times \mathrm{NH}_{4} \mathrm{Cl}$ interaction: $0.0 \mathrm{~mol}$ of $\mathrm{NH}_{4} \mathrm{Cl} / \mathrm{d}$ with $0.0 \mathrm{~kg}$ of starch $/ \mathrm{d}=10^{\mathrm{k}} ; 2.5 \mathrm{~mol}$ of NH $\mathrm{Nl}_{4} \mathrm{Cl} / \mathrm{d}$ with $0.0 \mathrm{~kg}$ of starch $/ \mathrm{d}=5^{\mathrm{k}}$; $5.0 \mathrm{~mol}$ of $\mathrm{NH}_{4} \mathrm{Cl} / \mathrm{d}$ with $0.0 \mathrm{~kg}$ of starch $/ \mathrm{d}=-7^{1} ; 0.0 \mathrm{~mol}$ of $\mathrm{NH}_{4} \mathrm{Cl} / \mathrm{d}$ with $3.0 \mathrm{~kg}$ of starch $/ \mathrm{d}=9^{\mathrm{k}} ; 2.5 \mathrm{~mol}$ of NH $\mathrm{NH}_{4} \mathrm{Cl} / \mathrm{d}$ with $3.0 \mathrm{~kg}$ of starch $/ \mathrm{d}$ $=-2^{1} ; 5.0 \mathrm{~mol}$ of $\mathrm{NH}_{4} \mathrm{Cl} / \mathrm{d}$ with $3.0 \mathrm{~kg}$ of $\operatorname{starch} / \mathrm{d}=-4^{1}$.

${ }^{6} \mathrm{Ground}$ corn $\times \mathrm{NH}_{4} \mathrm{Cl}$ interaction: $0.0 \mathrm{~mol}$ of $\mathrm{NH}_{4} \mathrm{Cl} / \mathrm{d}$ with $0.0 \mathrm{~kg}$ of starch $/ \mathrm{d}=34.0^{\mathrm{k}} ; 2.5 \mathrm{~mol}$ of NH $\mathrm{Nl}_{4} \mathrm{Cl}$ with $0.0 \mathrm{~kg}$ of starch $/ \mathrm{d}=29.4^{\mathrm{k}} ; 5.0$ $\mathrm{mol}$ of $\mathrm{NH}_{4} \mathrm{Cl} / \mathrm{d}$ with $0.0 \mathrm{~kg}$ of starch $/ \mathrm{d}=18.6^{\mathrm{l}} ; 0.0 \mathrm{~mol}$ of $\mathrm{NH}_{4} \mathrm{Cl} / \mathrm{d}$ with $3.0 \mathrm{~kg}$ of starch $/ \mathrm{d}=33.5^{\mathrm{k}} ; 2.5 \mathrm{~mol} \mathrm{of} \mathrm{NH} \mathrm{Nl}_{4} / \mathrm{d}$ with $3.0 \mathrm{~kg}$ of starch/d $=23.4^{1} ; 5.0 \mathrm{~mol}$ of $\mathrm{NH}_{4} \mathrm{Cl} / \mathrm{d}$ with $3.0 \mathrm{~kg}$ of $\mathrm{starch} / \mathrm{d}=21.3^{1}$.

${ }^{7}$ Ground corn $\times \mathrm{NH}_{4} \mathrm{Cl}$ interaction: $0.0 \mathrm{~mol}$ of $\mathrm{NH}_{4} \mathrm{Cl} / \mathrm{d}$ with $0.0 \mathrm{~kg}$ of starch $/ \mathrm{d}=35^{\mathrm{k}} ; 2.5 \mathrm{~mol}$ of NH $\mathrm{Nl}_{4} / \mathrm{d}$ with $0.0 \mathrm{~kg}$ of starch $/ \mathrm{d}=30^{\mathrm{k}} ; 5.0$ mol of $\mathrm{NH}_{4} \mathrm{Cl} / \mathrm{d}$ with $0.0 \mathrm{~kg}$ of starch $/ \mathrm{d}=20^{1} ; 0.0 \mathrm{~mol}$ of $\mathrm{NH}_{4} \mathrm{Cl} / \mathrm{d}$ with $3.0 \mathrm{~kg}$ of starch $/ \mathrm{d}=35^{\mathrm{k}} ; 2.5 \mathrm{~mol}$ of NH $\mathrm{Nl}_{4} \mathrm{Cl} / \mathrm{d}$ with $3.0 \mathrm{~kg}$ of starch $/ \mathrm{d}=$ $25 ; 5.0 \mathrm{~mol}$ of $\mathrm{NH}_{4} \mathrm{Cl} / \mathrm{d}$ with $3.0 \mathrm{~kg}$ of $\mathrm{starch} / \mathrm{d}=23$.

${ }^{8} \mathrm{O}_{2}$ saturation.

${ }^{9}$ Ground corn $\times \mathrm{NH}_{4} \mathrm{Cl}$ interaction: $0.0 \mathrm{~mol}$ of $\mathrm{NH}_{4} \mathrm{Cl} / \mathrm{d}$ with $0.0 \mathrm{~kg}$ of starch $/ \mathrm{d}=1.22^{\mathrm{k}} ; 2.5 \mathrm{~mol}$ of $\mathrm{NH} \mathrm{Cl}_{4} / \mathrm{d}$ with $0.0 \mathrm{~kg}$ of starch $/ \mathrm{d}=1.26^{\mathrm{km}}$; $5.0 \mathrm{~mol}$ of $\mathrm{NH}_{4} \mathrm{Cl} / \mathrm{d}$ with $0.0 \mathrm{~kg}$ of starch $/ \mathrm{d}=1.38^{\mathrm{ln}} ; 0.0 \mathrm{~mol}$ of $\mathrm{NH}_{4} \mathrm{Cl} / \mathrm{d}$ with $3.0 \mathrm{~kg}$ of starch $/ \mathrm{d}=1.23^{\mathrm{k}} ; 2.5 \mathrm{~mol}$ of NH $\mathrm{Nl}_{4} \mathrm{Cl} / \mathrm{d}$ with $3.0 \mathrm{~kg}$ of starch $/ \mathrm{d}=1.31^{\mathrm{mn}} ; 5.0 \mathrm{~mol}$ of $\mathrm{NH}_{4} \mathrm{Cl} / \mathrm{d}$ with $3.0 \mathrm{~kg}$ of $\operatorname{starch} / \mathrm{d}=1.32^{\mathrm{mn}}$.

${ }^{10} \mathrm{PCV}=$ packed cell volume; the ratio between the volume of red blood cells and the total volume of blood.

$\mathrm{NH}_{4} \mathrm{Cl} / \mathrm{d}$ increased $(P=0.019)$ blood potassium content relative to no $\mathrm{NH}_{4} \mathrm{Cl}$ infusion, but with no difference observed between 0.0 and $5.0 \mathrm{~mol}$ of $\mathrm{NH}_{4} \mathrm{Cl} / \mathrm{d}$ and between 2.5 and $5.0 \mathrm{~mol}$ of $\mathrm{NH}_{4} \mathrm{Cl} / \mathrm{d}$. Furthermore, 5.0 mol of $\mathrm{NH}_{4} \mathrm{Cl} / \mathrm{d}$ decreased $(P=0.038)$ blood glucose content relative to no $\mathrm{NH}_{4} \mathrm{Cl}$ infusion, with no difference between 0.0 and $2.5 \mathrm{~mol}$ of $\mathrm{NH}_{4} \mathrm{Cl} / \mathrm{d}$ and between 2.5 and $5.0 \mathrm{~mol}$ of $\mathrm{NH}_{4} \mathrm{Cl} / \mathrm{d}$. Infusion of $\mathrm{NH}_{4} \mathrm{Cl}$ tended to decrease blood sodium content $(P=0.065)$.

\section{Plasma Constituents}

Concerning laboratory blood plasma analyses, concentration of plasma triglycerides was affected by a ground corn $\times \mathrm{NH}_{4} \mathrm{Cl}$ interaction $(P=0.005$; Table 6 ). The effect of $\mathrm{NH}_{4} \mathrm{Cl}$ became apparent only in the absence of ground corn, where triglyceride concentration was higher with $5.0 \mathrm{~mol}$ of $\mathrm{NH}_{4} \mathrm{Cl} / \mathrm{d}$ compared with $2.5 \mathrm{~mol}$ of $\mathrm{NH}_{4} \mathrm{Cl} / \mathrm{d}$, with no difference between 0.0 and $2.5 \mathrm{~mol}$ of $\mathrm{NH}_{4} \mathrm{Cl} / \mathrm{d}$ and between 0.0 and 5.0 mol of $\mathrm{NH}_{4} \mathrm{Cl} / \mathrm{d}$. Plasma albumin concentration tended $(P=0.080)$ to be affected by a ground corn $\times \mathrm{NH}_{4} \mathrm{Cl}$ interaction, where $2.5 \mathrm{~mol}$ of $\mathrm{NH}_{4} \mathrm{Cl} / \mathrm{d}$ resulted in a numerically higher concentration than 0.0 and $5.0 \mathrm{~mol}$ of $\mathrm{NH}_{4} \mathrm{C} / \mathrm{d}$ in the presence of ground corn, but a numerically lower concentration in the absence of ground corn. Ground corn infusion decreased $(P<0.035)$ plasma concentrations of urea, insulin, BHB, and NEFA, and increased $(P=0.005)$ IGF-1 relative to no ground corn infusion. Regardless of ground corn inclusion, 2.5 and $5.0 \mathrm{~mol}$ of $\mathrm{NH}_{4} \mathrm{Cl} / \mathrm{d}$ decreased $(P=0.011)$ plasma haptoglobin concentration compared with no $\mathrm{NH}_{4} \mathrm{Cl}$ 
infusion, with no difference between 2.5 and $5.0 \mathrm{~mol}$ of $\mathrm{NH}_{4} \mathrm{Cl} / \mathrm{d}$.

\section{Energy and Nitrogen Balance}

None of the variables related to energy or nitrogen balance were affected by ground corn $\times \mathrm{NH}_{4} \mathrm{Cl}$ interactions (Table 7). Infusion of ground corn increased $(P<$ 0.040) the respiratory quotient, GE intake, energy excreted in manure, metabolizable energy intake (MEI), energy secreted in milk, total energy retention, and energy retained as fat, relative to no infusion of ground corn. Regardless of ground corn inclusion, $5.0 \mathrm{~mol}$ of $\mathrm{NH}_{4} \mathrm{Cl} / \mathrm{d}$ decreased $(P<0.001)$ metabolic BW relative to 0.0 and $2.5 \mathrm{~mol}$ of $\mathrm{NH}_{4} \mathrm{Cl} / \mathrm{d}$, with no difference observed between the latter 2. Additionally, $5.0 \mathrm{~mol}$ of $\mathrm{NH}_{4} \mathrm{Cl} / \mathrm{d}$ decreased $(P \leq 0.015)$ both $\mathrm{CH}_{4}$ production and energy retained as protein relative to no $\mathrm{NH}_{4} \mathrm{Cl}$ infusion, with no difference between 0.0 and $2.5 \mathrm{~mol}$ of $\mathrm{NH}_{4} \mathrm{Cl} / \mathrm{d}$ and between 2.5 and $5.0 \mathrm{~mol}$ of $\mathrm{NH}_{4} \mathrm{Cl} / \mathrm{d}$. Respiratory quotient and heat production tended to decrease with increasing level of $\mathrm{NH}_{4} \mathrm{Cl}$ infusion $(P \leq$ $0.068)$.

Infusion of ground corn increased $(P<0.006) \mathrm{N}$ excreted in feces, $\mathrm{N}$ secreted in milk, and $\mathrm{N}$ efficiency, and decreased $\mathrm{N}$ excreted in urine and $\mathrm{N}$ collected in condensed water and air, relative to no ground corn infusion. Regardless of ground corn inclusion, $5.0 \mathrm{~mol}$ of $\mathrm{NH}_{4} \mathrm{Cl} / \mathrm{d}$ increased $(P=0.002) \mathrm{N}$ excreted in urine relative to both 0.0 and $2.5 \mathrm{~mol}$ of $\mathrm{NH}_{4} \mathrm{Cl} / \mathrm{d}$, with no difference between the latter 2 . Infusion of $5.0 \mathrm{~mol}$ of
$\mathrm{NH}_{4} \mathrm{Cl} / \mathrm{d}$ decreased $(P \leq 0.042) \mathrm{N}$ excreted in feces and $\mathrm{N}$ balance relative to no $\mathrm{NH}_{4} \mathrm{Cl}$ infusion, with no difference observed between 0.0 and $2.5 \mathrm{~mol}$ of $\mathrm{NH}_{4} \mathrm{Cl} / \mathrm{d}$ and between 2.5 and $5.0 \mathrm{~mol}$ of $\mathrm{NH}_{4} \mathrm{Cl} / \mathrm{d}$. Nitrogen efficiency tended $(P=0.058)$ to increase with increasing infusion level of $\mathrm{NH}_{4} \mathrm{Cl}$ infusion.

\section{Rumen Fluid, Feces, and Urine}

The $\mathrm{pH}$ of rumen fluid, feces, and urine, as well as the total VFA content and VFA profile of rumen fluid and feces, were not affected by ground corn $\times \mathrm{NH}_{4} \mathrm{Cl}$ interactions (Table 8). None of the ruminal variables were affected by infusion of ground corn or $\mathrm{NH}_{4} \mathrm{Cl}$. Infusion of ground corn decreased $(P<0.001)$ fecal $\mathrm{pH}$, fecal isobutyrate proportion, fecal valerate proportion, and fecal isovalerate proportion, and increased total fecal VFA content and fecal butyrate proportion, relative to no ground corn infusion. Regardless of ground corn inclusion, 2.5 and $5.0 \mathrm{~mol}$ of $\mathrm{NH}_{4} \mathrm{Cl} / \mathrm{d}$ decreased $(P$ $<0.001$ ) urine $\mathrm{pH}$ compared with no $\mathrm{NH}_{4} \mathrm{Cl}$ infusion, with no difference between 2.5 and $5.0 \mathrm{~mol}$ of $\mathrm{NH}_{4} \mathrm{Cl} / \mathrm{d}$.

\section{DISCUSSION}

The aim of this study was to induce hindgut and metabolic acidosis via abomasal infusion of ground corn and $\mathrm{NH}_{4} \mathrm{Cl}$, respectively, and to determine the effects of these physiological states in early-lactating cows. We chose early-lactation cows because these are most prone to metabolic disorders. Importantly, rumen fermenta-

Table 6. Blood plasma constituents of early-lactation dairy cows abomasally infused with ground corn and $\mathrm{NH}_{4} \mathrm{Cl}$

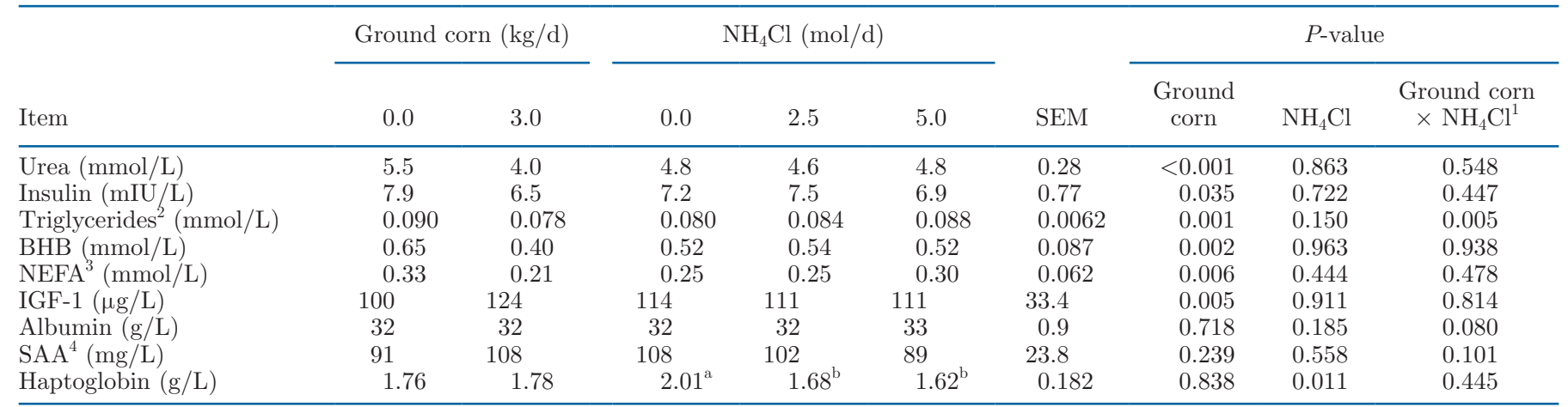

\footnotetext{
${ }^{\mathrm{a}, \mathrm{b}}$ Values with different superscripts indicate a significant difference $(P<0.05)$ between $0.0,2.5$, and $5.0 \mathrm{~mol} \mathrm{of} \mathrm{NH} \mathrm{H}_{4} \mathrm{Cl} / \mathrm{d}$.

${ }^{1}$ Interaction between 2 levels of ground corn $(0.0$ or $3.0 \mathrm{~kg} / \mathrm{d})$ and 3 levels of $\mathrm{NH}_{4} \mathrm{Cl}(0.0,2.5$, or $5.0 \mathrm{~mol} / \mathrm{d})$. If a significant ground corn $\times$ $\mathrm{NH}_{4} \mathrm{Cl}$ interaction is found, a different superscript $(\mathrm{k}-\mathrm{l})$ in the footnote of that particular variable indicates a significant difference $(P<0.05)$. ${ }^{2}$ Ground corn $\times \mathrm{NH}_{4} \mathrm{Cl}$ interaction: $0.0 \mathrm{~mol}$ of $\mathrm{NH}_{4} \mathrm{Cl} / \mathrm{d}$ with $0.0 \mathrm{~kg}$ of starch $/ \mathrm{d}=0.086^{\mathrm{kl}} ; 2.5 \mathrm{~mol}$ of NH $4 \mathrm{Cl} / \mathrm{d}$ with $0.0 \mathrm{~kg}$ of starch $/ \mathrm{d}=0.082^{\mathrm{k}}$; $5.0 \mathrm{~mol}$ of $\mathrm{NH}_{4} \mathrm{Cl} / \mathrm{d}$ with $0.0 \mathrm{~kg}$ of starch $/ \mathrm{d}=0.102^{\mathrm{l}} ; 0.0 \mathrm{~mol}$ of $\mathrm{NH}_{4} \mathrm{Cl} / \mathrm{d}$ with $3.0 \mathrm{~kg}$ of starch $/ \mathrm{d}=0.074^{\mathrm{k}} ; 2.5 \mathrm{~mol}$ of NH $\mathrm{Nl}_{4} / \mathrm{d}$ with $3.0 \mathrm{~kg}$ of starch $/ \mathrm{d}=0.085^{\mathrm{k}} ; 5.0 \mathrm{~mol}$ of $\mathrm{NH}_{4} \mathrm{Cl} / \mathrm{d}$ with $3.0 \mathrm{~kg}$ of $\mathrm{starch} / \mathrm{d}=0.075^{\mathrm{k}}$.

${ }^{3}$ Nonesterified fatty acids.

${ }^{4}$ Serum amyloid A.
} 
tion remained unaffected by the infusion of both ground corn and $\mathrm{NH}_{4} \mathrm{Cl}$, suggesting no appreciable back-flow of infusates into the rumen, particularly of ground corn.

\section{Establishment of Hindgut Acidosis}

Fecal total VFA concentration increased upon abomasal infusion of ground corn, suggesting increased hindgut fermentation. Increased hindgut fermentation is also illustrated by the reduction in ATTD of CP, likely the result of increased microbial protein synthesis upon fermentation of a part of the infused ground corn, as well as the increased respiratory quotient values that can arise from increased anaerobic fermentation of di- etary carbohydrates (Gerrits et al., 2015). The observed hindgut $\mathrm{pH}$ values (i.e., 6.00 and $6.86 \mathrm{pH}$ units for treatment with and without ground corn, respectively) suggest that the increased hindgut fermentation of the infused ground corn resulted in hindgut acidosis, where the $\mathrm{pH}$ threshold typically considered for hindgut acidosis ranges from 6.0 to 6.6 (Metzler-Zebeli et al., 2013). Although moderate amounts of starch were fermented in the hindgut, it still caused acidosis because of the lack of salivary buffering and absence of protozoa limiting the ability of the hindgut to self-regulate digesta $\mathrm{pH}$ (Gressley et al., 2011).

The lack of simple models to simulate hindgut fermentation has limited the research focus on hindgut

Table 7. Energy and nitrogen balance (based on $\mathrm{TMR}+$ infusion) of early-lactation dairy cows abomasally infused with ground corn and $\mathrm{NH}_{4} \mathrm{Cl}$

\begin{tabular}{|c|c|c|c|c|c|c|c|c|c|}
\hline \multirow[b]{2}{*}{ Item } & \multicolumn{2}{|c|}{ Ground corn $(\mathrm{kg} / \mathrm{d})$} & \multicolumn{3}{|c|}{$\mathrm{NH}_{4} \mathrm{Cl}(\mathrm{mol} / \mathrm{d})$} & \multirow[b]{2}{*}{ SEM } & \multicolumn{3}{|c|}{$P$-value } \\
\hline & 0.0 & 3.0 & 0.0 & 2.5 & 5.0 & & $\begin{array}{l}\text { Ground } \\
\text { corn }\end{array}$ & $\mathrm{NH}_{4} \mathrm{Cl}$ & $\begin{array}{l}\text { Ground corn } \\
\quad \times \mathrm{NH}_{4} \mathrm{Cl}^{1}\end{array}$ \\
\hline Respiratory quotient & 1.08 & 1.11 & 1.11 & 1.10 & 1.08 & 0.017 & 0.013 & 0.052 & 0.214 \\
\hline Metabolic BW' $\left(\mathrm{kg}^{0.75}\right)$ & 112 & 111 & $113^{\mathrm{a}}$ & $112^{\mathrm{a}}$ & $110^{\mathrm{b}}$ & 1.6 & 0.456 & $<0.001$ & 0.133 \\
\hline \multicolumn{10}{|l|}{$\begin{array}{l}\text { Energy balance (kJ } / \mathrm{kg} \\
\text { of BW } \\
\text { unless stated otherwise) }\end{array}$} \\
\hline $\mathrm{CH}_{4}$ production & 146 & 136 & $153^{\mathrm{a}}$ & $143^{\mathrm{ab}}$ & $126^{\mathrm{b}}$ & 8.5 & 0.119 & 0.009 & 0.127 \\
\hline Energy in manure & 682 & 785 & 762 & 747 & 692 & 33.9 & 0.002 & 0.143 & 0.545 \\
\hline $\mathrm{DEI}^{4}$ & 1,539 & 1,645 & 1,645 & 1,613 & 1,518 & 79.9 & 0.112 & 0.275 & 0.259 \\
\hline $\mathrm{MEI}^{5}$ & 1,366 & 1,530 & 1,509 & 1,472 & 1,362 & 80.3 & 0.016 & 0.170 & 0.355 \\
\hline MEI to GEI ratio (\%) & 62.2 & 62.3 & 62.1 & 62.3 & 62.4 & 0.62 & 0.797 & 0.876 & 0.774 \\
\hline Heat production ${ }^{6}$ & 832 & 837 & 860 & 840 & 804 & 20.4 & 0.802 & 0.068 & 0.535 \\
\hline Energy in milk & 585 & 624 & 604 & 621 & 589 & 24.0 & 0.040 & 0.349 & 0.940 \\
\hline $\mathrm{N}$ intake & 3,866 & 3,876 & 4,024 & 3,933 & 3,656 & 194.7 & 0.944 & 0.102 & 0.436 \\
\hline $\mathrm{N}$ manure & 2,619 & 2,628 & 2,645 & 2,645 & 2,581 & 120.1 & 0.883 & 0.619 & 0.378 \\
\hline $\mathrm{N}$ feces ${ }^{10}$ & 1,226 & 1,459 & $1,445^{\mathrm{a}}$ & $1,382^{\mathrm{ab}}$ & $1,200^{\mathrm{b}}$ & 94.9 & 0.006 & 0.042 & 0.398 \\
\hline $\mathrm{N}$ urine $^{11}$ & 1,394 & 1,182 & $1,206^{\mathrm{a}}$ & $1,262^{\mathrm{a}}$ & $1,395^{\mathrm{b}}$ & 60.2 & $<0.001$ & 0.002 & 0.303 \\
\hline $\mathrm{N}$ milk & 854 & 968 & 904 & 932 & 897 & 32.1 & $<0.001$ & 0.462 & 0.926 \\
\hline $\mathrm{N}$ condense $+\mathrm{N}$ acid & 74 & 60 & 69 & 67 & 65 & 12.6 & $<0.001$ & 0.708 & 0.655 \\
\hline $\mathrm{N}$ balance & 319 & 218 & $408^{\mathrm{a}}$ & $290^{\mathrm{ab}}$ & $106^{\mathrm{b}}$ & 82.4 & 0.195 & 0.015 & 0.190 \\
\hline $\mathrm{N}$ efficiency ${ }^{12}$ & 22.3 & 25.3 & 22.7 & 23.9 & 24.9 & 1.05 & $<0.001$ & 0.058 & 0.161 \\
\hline
\end{tabular}

${ }_{\mathrm{a}, \mathrm{b}}$ Values with different superscripts indicate a significant difference $(P<0.05)$ between $0.0,2.5$, and $5.0 \mathrm{~mol} \mathrm{of} \mathrm{NH} \mathrm{H}_{4} \mathrm{Cl} / \mathrm{d}$.

${ }^{1}$ Interaction between 2 levels of ground corn $(0.0$ or $3.0 \mathrm{~kg} / \mathrm{d})$ and 3 levels of $\mathrm{NH}_{4} \mathrm{Cl}(0.0,2.5$, or $5.0 \mathrm{~mol} / \mathrm{d})$.

${ }^{2}$ Mean BW per cow per balance period was used to calculate metabolic BW $\left(\mathrm{BW}^{0.75}\right)$.

${ }^{3}$ Gross energy intake (diet + infusion).

${ }^{4}$ DEI $($ digestible energy intake $)=$ GEI $\times$ apparent total-tract digestibility of GE $(\%$ of intake $) / 100$.

${ }^{5} \mathrm{MEI}$ (metabolizable energy intake) = GEI - methane production - energy in feces - energy in urine.

${ }^{6}$ Heat production $(\mathrm{kJ} / \mathrm{d})=16.175 \times \mathrm{VO}_{2}(\mathrm{~L} / \mathrm{d})+5.021 \times \mathrm{VCO}_{2}(\mathrm{~L} / \mathrm{d})$, where $\mathrm{VO}_{2}=$ volumes of $\mathrm{O}_{2}$ consumed, and $\mathrm{VCO}_{2}=$ volumes of $\mathrm{CO}_{2}$ produced (Gerrits et al., 2015).

${ }^{7}$ Energy retention total $=$ MEI - heat production - energy in milk.

${ }^{8}$ Energy retention protein $=$ protein gain $(\mathrm{N} \times 6.25) \times 23.6 \mathrm{~kJ} / \mathrm{g}($ energetic value of protein $)$.

${ }^{9}$ Energy retention fat $=$ energy retention total - energy retention protein.

${ }^{10} \mathrm{~N}$ feces $=\mathrm{N}$ intake $\times[100-$ apparent total-tract digestibility of $\mathrm{N}(\%$ of intake $)] / 100$.

${ }^{11} \mathrm{~N}$ urine $=\mathrm{N}$ manure $-\mathrm{N}$ feces.

${ }^{12} \mathrm{~N}$ efficiency $=\mathrm{N}$ milk/ $\mathrm{N}$ intake $(\%)$. 
Table 8. $\mathrm{pH}$ and volatile fatty acids (VFA) of rumen fluid, feces, and urine ( $\mathrm{pH}$ only) of early-lactation dairy cows abomasally infused with ground corn and $\mathrm{NH}_{4} \mathrm{Cl}$

\begin{tabular}{|c|c|c|c|c|c|c|c|c|c|}
\hline \multirow[b]{2}{*}{ Item } & \multicolumn{2}{|c|}{ Ground corn (kg/d) } & \multicolumn{3}{|c|}{$\mathrm{NH}_{4} \mathrm{Cl}(\mathrm{mol} / \mathrm{d})$} & \multirow[b]{2}{*}{ SEM } & \multicolumn{3}{|c|}{$P$-value } \\
\hline & 0.0 & 3.0 & 0.0 & 2.5 & 5.0 & & $\begin{array}{l}\text { Ground } \\
\text { corn }\end{array}$ & $\mathrm{NH}_{4} \mathrm{Cl}$ & $\begin{array}{l}\text { Ground corn } \\
\quad \times \mathrm{NH}_{4} \mathrm{Cl}^{1}\end{array}$ \\
\hline \multicolumn{10}{|l|}{ Rumen fluid } \\
\hline $\mathrm{pH}$ & 6.31 & 6.22 & 6.32 & 6.26 & 6.23 & 0.117 & 0.119 & 0.453 & 0.656 \\
\hline Total VFA $(\mathrm{m} M)$ & 108 & 108 & 109 & 105 & 110 & 4.3 & 0.981 & 0.297 & 0.942 \\
\hline \multicolumn{10}{|l|}{ VFA ( $\%$ of total VFA) } \\
\hline Butyrate & 9.5 & 9.3 & 9.6 & 9.6 & 9.1 & 0.24 & 0.329 & 0.125 & 0.104 \\
\hline Isobutyrate & 0.63 & 0.62 & 0.64 & 0.62 & 0.62 & 0.019 & 0.883 & 0.594 & 0.681 \\
\hline Valerate & 1.41 & 1.42 & 1.46 & 1.42 & 1.36 & 0.052 & 0.800 & 0.459 & 0.913 \\
\hline Isovalerate & 1.14 & 1.05 & 1.07 & 1.11 & 1.10 & 0.103 & 0.242 & 0.897 & 0.814 \\
\hline \multicolumn{10}{|l|}{ Feces } \\
\hline $\mathrm{pH}$ & 6.86 & 6.00 & 6.52 & 6.40 & 6.37 & 0.116 & $<0.001$ & 0.480 & 0.729 \\
\hline \multicolumn{9}{|l|}{ VFA ( $\%$ of total VFA) } & 0.355 \\
\hline Valerate & 1.17 & 0.36 & 0.83 & 0.73 & 0.75 & 0.054 & $<0.001$ & 0.397 & 0.915 \\
\hline Isovalerate & 1.18 & 0.57 & 0.88 & 0.87 & 0.88 & 0.096 & $<0.001$ & 0.996 & 0.730 \\
\hline \multicolumn{10}{|l|}{ Urine } \\
\hline $\mathrm{pH}$ & 6.74 & 6.57 & $7.91^{\mathrm{a}}$ & $6.10^{\mathrm{b}}$ & $5.96^{\mathrm{b}}$ & 0.181 & 0.170 & $<0.001$ & 0.531 \\
\hline
\end{tabular}

${ }^{\mathrm{a}, \mathrm{b}}$ Values with different superscripts indicate a significant difference $(P<0.05)$ between $0.0,2.5$, and $5.0 \mathrm{~mol} \mathrm{of} \mathrm{NH}{ }_{4} \mathrm{Cl} / \mathrm{d}$.

${ }^{1}$ Interaction between 2 levels of ground corn $(0.0$ or $3.0 \mathrm{~kg} / \mathrm{d})$ and 3 levels of $\mathrm{NH}_{4} \mathrm{Cl}(0.0,2.5$, or $5.0 \mathrm{~mol} / \mathrm{d})$.

acidosis (Plaizier et al., 2018). We were able to induce hindgut acidosis via infusion of ground corn into the abomasum, and the subsequent effects will subsequently be discussed in detail. However, our results might differ from previous findings in which hindgut acidosis was induced via different models. Several studies (e.g., Li et al., 2012; Plaizier et al., 2017) induced hindgut acidosis via a grain-based SARA challenge. This model is effective at increasing the risk of hindgut acidosis, because feeding large amounts of grain, combined with poor rumen mat function associated with SARA conditions, leads to larger amounts of fermentable substrates that bypass rumen fermentation and are subsequently fermented in the hindgut (Plaizier et al., 2018). Our model (i.e., abomasal infusion) induced hindgut acidosis but did not affect ruminal conditions, which represents a potentially important difference that could affect the responses observed in the current study.

\section{Effects of Abomasal Ground Corn Infusion and Associated Hindgut Acidosis}

Nutrient Intake and Digestibility. Ground corn infusion increased the total intake of several nutrients. This is a direct consequence of the treatment design, where, on average, a realized $2.7 \mathrm{~kg} / \mathrm{d}$ of ground corn was infused and added to calculated TMR intake.
Others (Knowlton et al., 1998; Reynolds et al., 1998) observed a depressed voluntary DMI upon postruminal infusion of ground corn, whereas the DMI of the TMR was not decreased upon ground corn infusion in the current study $(P=0.161$, results not shown). Likely, the cows in the present study may not have shown a reduction in their voluntary DMI because of the already relatively low DMI of the TMR (i.e., $13.3 \mathrm{~kg} / \mathrm{d}$ for the treatment without ground corn and $\mathrm{NH}_{4} \mathrm{Cl}$ vs. the calculated feed intake capacity of $18.8 \mathrm{~kg} \mathrm{DM} / \mathrm{d}$ at $95 \%$ feeding level; Zom et al., 2012). This may have been a result of low palatability of the grass silage, which by design had a low DCAD value (i.e., $184 \mathrm{mEq} /$ $\mathrm{kg}$ of DM relative to the Dutch average of $439 \mathrm{mEq} / \mathrm{kg}$ of DM; CVB, 2018) and high Cl content (i.e., $19.5 \mathrm{~g} /$ $\mathrm{kg}$ of DM relative to the Dutch average of $12.3 \mathrm{~g} / \mathrm{kg}$ of DM; CVB, 2018).

The decreased ATTD of most nutrients, except for fat (not affected) and starch (increased), upon abomasal infusion of ground corn is contrary to previous reports by Knowlton et al. (1998) and Reynolds et al. (2001), and may be the result of multiple factors. The ground corn was infused to bypass the rumen, likely reducing overall fermentation and absorption of the nutrients that were infused. Furthermore, the decreased $\mathrm{pH}$ of the hindgut upon ground corn infusion potentially affected the hindgut microbiome. Fibrolytic bacteria 
are generally inhibited by a lower $\mathrm{pH}$, decreasing fiber fermentation and, subsequently, fiber digestibility. The decreased ATTD of CP was also observed by Gressley and Armentano $(2005,2007)$ and Gressley et al. (2011), and is likely the result of increased microbial protein synthesis upon fermentation of a part of the infused ground corn. This microbial protein remains undigested and thereby decreases ATTD of N (Ørskov et al., 1969; Owens et al., 1986). The increase in ATTD of starch in response to ground corn infusion may be due to low starch content of the basal diet leading to a lower apparent fecal starch digestibility compared with the digestibility of the infused starch.

Energy Partitioning. The increased GE intake, in combination with decreased ATTD of GE, resulted in increased energy excreted via manure when ground corn was infused. The relative increase in GE intake was more pronounced than the relative decrease in ATTD of GE. In addition, methane energy loss was numerically lower for the infusions containing ground corn. This resulted in a higher MEI with the abomasal infusion of ground corn. The increased MEI could subsequently be used for milk production, which is evident by the observed increase in milk yield and energy secreted in milk, but also for body tissue synthesis (Reynolds et al., 2001), particularly when the increase in MEI arises from glucogenic energy (Nichols et al., 2019). The latter is evidenced by the increased total energy retained as well as energy retained as body fat during ground corn infusion.

Milk yield is largely regulated through the osmotic properties of lactose, synthesis of which requires the transport of glucose from blood into the cytosol of mammary epithelial cells (Cant et al., 2002). There is a considerable capacity for starch digestion in the small intestines via enzymatic hydrolysis resulting in increased glucose supply to the animal (Reynolds, 2006). Glucose concentration in whole-blood increased with ground corn infusion in the current study (Table 5) as well as milk lactose content and lactose yield. This response is in line with the findings of Rius et al. (2010a) and Knowlton et al. (1998). A decrease in milk fat content was observed with abomasal infusion of ground corn in the present study, which is contrary to Knowlton et al. (1998) but in agreement with Rius et al. (2010a). When elevated in circulation, propionate and glucose promote insulin secretion (Bauman and Griinari, 2001). Insulin stimulates uptake of lipogenic precursors and reduces lipolysis in adipose tissue, resulting in reduced circulating fatty acids for milk fat synthesis (Bauman and Griinari, 2001). Although an increase in glucose concentration was observed in response to ground corn infusion in the current study, serum insulin concentrations actually were decreased. Despite the latter, decreased NEFA and BHB concentrations in plasma, decreased acetone and BHB concentrations in milk, and increased energy retention as fat indicate a reduced availability of fatty acids for milk lipid synthesis.

Nitrogen Partitioning. The increased milk protein yield with abomasal infusion of ground corn is contrary to findings of Knowlton et al. (1998), Reynolds et al. (2001), and Rius et al. (2010a). Increased milk protein yield in the present study was mainly caused by increased milk yield, as milk protein content was unaffected. Increased arterial glucose concentrations in response to infusion of ground corn suggest an elevated absorptive glucose supply, which may have supported the increased transfer of dietary $\mathrm{N}$ into milk $\mathrm{N}$, in part due to reduced catabolism of AA for gluconeogenesis (Rulquin et al., 2004; Rius et al., 2010a,b).

The clear shift from urinary $\mathrm{N}$ to fecal $\mathrm{N}$ upon abomasal infusion of ground corn is likely related to fermentation of part of the infused ground corn in the large intestine leading to increased microbial protein synthesis. Because the N source for this microbial protein is partly derived from blood next to $\mathrm{N}$ sources in the digesta, this leads to a shift in $\mathrm{N}$ excretion from the urine to the feces (Heijnen and Beynen, 1997), as also observed by Reynolds et al. (2001). In cows, the amount of urea excreted in urine is directly proportional, although with considerable variation (Spek et al., 2013), to its concentration in blood (Ciszuk and Gebregziabher, 1994). In support of this, plasma urea decreased in the present study. This can indicate that urea was drawn from plasma to contribute to fecal $\mathrm{N}$ at the cost of urine $\mathrm{N}$ excretion, because increased hindgut fermentation stimulates assimilation of $\mathrm{NH}_{3}$ in microbial protein rather than its absorption into the bloodstream, resulting in lower urea production by the liver. Lower plasma urea with ground corn infusion also agrees with reduced AA catabolism in response to increased glucose supply.

Immune Response. We hypothesized that hindgut fermentation of the abomasally infused ground corn would stimulate a systemic inflammatory response. Systemic inflammation can result from the translocation of endotoxins, such as LPS, from the digestive tract to blood. During rapid growth or lysis of bacteria, LPS is released from the bacterial cell walls and animal tissue becomes exposed to these toxic components (Hurley, 1995; Wells and Russell, 1996). Several studies have observed that grain-induced SARA challenges increase the free LPS content of digesta in the large intestine and feces (e.g., Li et al., 2016; Qumar et al., 2017), likely as a result of hindgut acidosis caused by increased amounts of starch that bypasses rumen fermentation and digestion in the small intestine (Gressley et al., 2011). 
The simpler structure makes the hindgut epithelium more susceptible than the rumen epithelium to barrier damage and toxin translocation under acidic conditions (Tao et al., 2014), impacting on the animal. The barrier function of the monolayer epithelium of the large intestine for LPS may thus be compromised relatively easily (Emmanuel et al., 2007; Plaizier et al., 2012), and high LPS in the large intestine may therefore pose a risk for systemic inflammation (Plaizier et al., 2018). However, the absence of effect of abomasally infused ground corn on the plasma concentrations of the acutephase proteins haptoglobin, albumin, and SAA in the current study suggests that hindgut fermentation of the infused ground corn did not result in a systemic inflammatory response. Although systemic inflammation was not detected by these plasma markers, this does not preclude the possibility that the epithelium of the large intestine became (or would become, in the longer term) more susceptible to damage or increased permeability (not tested in the current study).

\section{Establishment of Metabolic Acidosis}

Cows receiving $5.0 \mathrm{~mol}$ of $\mathrm{NH}_{4} \mathrm{Cl}$ without ground corn or 2.5 and $5.0 \mathrm{~mol}$ of $\mathrm{NH}_{4} \mathrm{Cl} / \mathrm{d}$ with ground corn had a blood $\mathrm{pH}$ below 7.40, a blood $\mathrm{HCO}_{3}$ concentration below $25.0 \mathrm{mmol} / \mathrm{L}$, and a negative base excess. This blood profile suggests that the cows experienced subacute metabolic acidosis (Schotman, 1971). The absorption of $\mathrm{Cl}$ from the gastrointestinal tract reduces the strong ion difference in body fluids. In an effort to maintain the acid-base equilibrium, $\mathrm{HCO}_{3}$ is depleted and $\mathrm{H}^{+}$is released, resulting in decreased blood $\mathrm{pH}(\mathrm{Hu}$ and Murphy, 2004). The observed interactions between ground corn and $\mathrm{NH}_{4} \mathrm{Cl}$ for blood $\mathrm{pH}, \mathrm{HCO}_{3}$, partial pressure of $\mathrm{CO}_{2}\left(\mathrm{pCO}_{2}\right.$; tendency only), base excess, and total $\mathrm{CO}_{2}$, indicate that the effect of $\mathrm{NH}_{4} \mathrm{Cl}$ infusion on the acid-base status was affected by the presence of abomasal ground corn infusion. This is likely related to increased VFA absorption from the hindgut during ground corn infusion. In the rumen, absorption of VFA is suspected to be primarily regulated by the anion exchange pathway, where VFA are absorbed in exchange for the secretion of $\mathrm{HCO}_{3}$ (Aschenbach et al., 2009). An acid load in the rumen depleted $\mathrm{HCO}_{3}$ from the blood in beef steers (Brown et al., 2000) and decreased blood $\mathrm{pH}$. This mechanism is likely valid for the hindgut as well, especially when excessive fermentation takes place. Abomasal ground corn infusion induced hindgut fermentation in the present study, which explains the stronger effect of $\mathrm{NH}_{4} \mathrm{Cl}$ infusion on the acid-base status of dairy cows in the presence of ground corn.

Irrespective of treatment, we observed positive relationships $(\mathrm{n}=36)$ between the overall DCAD value (in
$\mathrm{mEq} / \mathrm{kg}$ of DM; basal diet + infusion treatments; Table 1) and blood $\mathrm{pH}(\mathrm{r}=0.72, P<0.001)$, blood $\mathrm{HCO}_{3}$ concentration $(\mathrm{r}=0.80, P<0.001)$, and blood $\mathrm{pCO}_{2}$ $(\mathrm{r}=0.60, P<0.001)$. This is in agreement with the relationships observed by $\mathrm{Hu}$ and Murphy (2004). Blood $\mathrm{HCO}_{3}$ pattern follows blood $\mathrm{pH}$ response according to the Henderson-Hasselbalch equation: blood $\mathrm{pH}=6.1+$ $\log _{10}\left[\mathrm{HCO}_{3} /\left(0.03 \times \mathrm{pCO}_{2}\right)\right](\mathrm{Hu}$ and Murphy, 2004). In clinically healthy cows, acid-base disturbances are compensated by various regulatory mechanisms (Gärtner et al., 2019), with the kidneys fulfilling a prominent role through ion transport mechanisms and through reabsorption and synthesis of $\mathrm{HCO}_{3}$ and the accompanying excretion of $\mathrm{H}^{+}$(Enemark et al., 2002). The efficient renal elimination of excess of anions, such as $\mathrm{Cl}$ upon infusion of $\mathrm{NH}_{4} \mathrm{Cl}$, causes a reduction in urinary $\mathrm{pH}$ (Wang et al., 2018), which we did observe in response to $\mathrm{NH}_{4} \mathrm{Cl}$ infusion in the current study.

\section{Effects of Abomasal $\mathrm{NH}_{4} \mathrm{Cl}$ Infusion and Associated Metabolic Acidosis}

Nutrient Intake and Digestibility. The tendency toward decreased DMI of the TMR with infusion of $5.0 \mathrm{~mol}$ of $\mathrm{NH}_{4} \mathrm{Cl} / \mathrm{d}$, irrespective of ground corn infusion, appears mainly due to the successful induction of metabolic acidosis. Zimpel et al. (2018) recently concluded that the decrease in DMI of dry pregnant cows in response to diets with negative DCAD was mediated by metabolic acidosis and not by the presence of acidogenic products or salts containing $\mathrm{Cl}$ in dietary DM (i.e., palatability). This conclusion was supported by a linear relationship between blood $\mathrm{pH}$ and DMI. Similarly, in the present study, blood $\mathrm{pH}$ was positively related to both total DMI $(\mathrm{r}=0.64, P=0.003)$ and DMI of the TMR $(\mathrm{r}=0.49, P<0.001)$.

Iwaniuk and Erdman (2015) reported a linear positive relation between dietary DCAD concentration (ranging between 13 and $436 \mathrm{mEq} / \mathrm{kg}$ of $\mathrm{DM}$ ) and the ATTD of DM and NDF, where changes in fiber digestibility due to variation in DCAD were likely the result of changes in ruminal pH (e.g., Erdman et al., 1982; West et al., 1987). In contrast, we did not observe an effect of $\mathrm{NH}_{4} \mathrm{Cl}$ on the ATTD of DM and NDF, and ruminal $\mathrm{pH}$, likely due to the method of infusion of $\mathrm{NH}_{4} \mathrm{Cl}$ into the abomasum. Increased digestibility of CP, crude fat, and starch at the highest level of $\mathrm{NH}_{4} \mathrm{Cl}$ infusion compared with no $\mathrm{NH}_{4} \mathrm{Cl}$ infusion was likely the result of the lower TMR DMI, allowing a longer retention time in the rumen and increased ruminal fermentation of these components (Colucci et al., 1989).

Energy Partitioning. The lower metabolic BW of the cows when they received $5.0 \mathrm{~mol}$ of $\mathrm{NH}_{4} \mathrm{Cl} / \mathrm{d}$ compared with $2.5 \mathrm{~mol}$ of $\mathrm{NH}_{4} \mathrm{Cl} / \mathrm{d}$ is likely a result of the 
lower DMI and subsequently less feed in the gastrointestinal tract and lower digesta content weight. Milk yield as well as energy secreted in milk were not affected by $\mathrm{NH}_{4} \mathrm{Cl}$, which is in line with Chan et al. (2005), Roche et al. (2003, 2005), and Apper-Bossard et al. (2006), although others have reported linear increases in milk yield with increasing DCAD concentration in dietary DM (Tucker et al., 1988; Apper-Bossard et al., 2010). The meta-analyses of $\mathrm{Hu}$ and Murphy (2004) and more recently of Iwaniuk and Erdman (2015) demonstrated a nonlinear milk yield response to increasing DCAD concentration in dietary DM.

The lack of effect of $\mathrm{NH}_{4} \mathrm{Cl}$ on milk fat content and yield in the present study is in agreement with Tucker et al. (1988), Chan et al. (2005), and Roche et al. (2003), but contrary to Iwaniuk and Erdman (2015), Apper-Bossard et al. $(2006,2010)$ and Roche et al. (2005), who all reported increases in milk fat content and yield with increasing DCAD values. These previous studies manipulated the DCAD value via the addition of cation or anion sources to the diet fed, potentially affecting rumen fermentation. Iwaniuk and Erdman (2015) reported a positive linear relation between the DCAD value and ruminal $\mathrm{pH}$ and the molar proportions of acetate and butyrate, all of which have been associated with increased milk fat content (Kolver and de Veth, 2002; Jenkins et al., 2014). In the current study, however, the DCAD value of the basal diet was similar for all treatments, and $\mathrm{NH}_{4} \mathrm{Cl}$ was infused into the abomasum, preventing effects at the rumen level and its consequences downstream on milk fat synthesis. The decrease in milk lactose content with increasing levels of $\mathrm{NH}_{4} \mathrm{Cl}$ infusion is contrary to Roche et al. (2003) and Apper-Bossard et al. (2006) but in agreement with Wang et al. (2018). The main constituents involved in maintaining the osmotic pressure of milk, which is always closely related to the osmotic pressure of blood, are lactose, $\mathrm{Na}, \mathrm{K}$, and $\mathrm{Cl}$ (Bijl et al., 2013). Wang et al. (2018) observed a linear increase in serum $\mathrm{Cl}$ concentrations with increasing dose of $\mathrm{NH}_{4} \mathrm{Cl}$ in ruminal infusions, and $\mathrm{Hu}$ and Murphy (2004) reported a positive linear relation between dietary $\mathrm{Cl}$ content and $\mathrm{Cl}$ concentration in the blood. Concentration and electrical gradients in the mammary gland between extra- and intracellular fluid and milk tend to drive $\mathrm{Cl}$ into milk (Peaker, 1983; Shennan and Peaker, 2000). Although not measured in the current study, the abomasal infusion of $\mathrm{NH}_{4} \mathrm{Cl}$ likely resulted in increased $\mathrm{Cl}$ concentrations in both blood and milk. Bijl et al. (2013) reported an inverse relationship between milk lactose content and milk $\mathrm{Cl}$ concentrations $(\mathrm{r}=-0.66$, $P<0.01$ ), potentially explaining the decreasing milk lactose content with increased levels of $\mathrm{NH}_{4} \mathrm{Cl}$ infusion observed in the present study.
Nitrogen Partitioning. The unaffected milk protein content and yield with infusion of $\mathrm{NH}_{4} \mathrm{Cl}$ is in agreement with the findings of Tucker et al. (1988), Chan et al. (2005), and Iwaniuk and Erdman (2015), and is likely due to the unaffected $\mathrm{N}$ intake. Our results indicate that metabolic acidosis induced by high levels of abomasal infusion of $\mathrm{NH}_{4} \mathrm{Cl}$ stimulates partitioning of body $\mathrm{N}$ toward urinary $\mathrm{N}$ excretion, because $\mathrm{N}$ balance decreased with infusion of $\mathrm{NH}_{4} \mathrm{Cl}$ and fecal $\mathrm{N}$ shifted to urinary $\mathrm{N}$ excretion.

Immune Response. Plasma haptoglobin, but not plasma albumin or SAA, decreased in response to infusion of $\mathrm{NH}_{4} \mathrm{Cl}$. Haptoglobin is an acute-phase protein that plays an essential role in immune cell function and tissue repair (Roche et al., 2013). Haptoglobin production is initiated by proinflammatory cytokines released at sites of infection or tissue damage (Carroll et al., 2009). The concentrations of haptoglobin in the present study were well above concentrations of 0.8 to $1.0 \mathrm{~g} / \mathrm{L}$, regardless of treatment, suggesting that the early-lactation cows in the present study would have to be classified as animals at high risk for periparturient diseases (Huzzey et al., 2009; Dubuc et al., 2010). Haptoglobin was not associated with SCC or $\log _{10}$ SCC (both $P>0.100$ ), suggesting that mastitis was not the basis for these relatively high haptoglobin concentrations, in agreement with the lack of clinical signs or treatment of mastitis (or any other disease) during the experiment. It is possible that the metabolic challenge induced by infusion of high doses of $\mathrm{NH}_{4} \mathrm{Cl}$ may have affected immune responses such that haptoglobin production was inhibited. However, the mode of action behind this hypothesis cannot be elucidated based on the measurements in the current study.

\section{CONCLUSIONS}

Abomasal infusion of $\mathrm{NH}_{4} \mathrm{Cl}$ affected the acid-base status of dairy cows, and this occurred more strongly when ground corn was also infused in the abomasum. Metabolic acidosis was observed with abomasal infusion of $5.0 \mathrm{~mol}$ of $\mathrm{NH}_{4} \mathrm{Cl} / \mathrm{d}$ in the absence of ground corn and with abomasal infusion of both 2.5 and $5.0 \mathrm{~mol}$ of $\mathrm{NH}_{4} \mathrm{Cl} / \mathrm{d}$ in the presence of ground corn. Metabolic acidosis increased urinary $\mathrm{N}$ excretion while decreasing fecal $\mathrm{N}$ excretion, and decreased energy retained as protein. Abomasal ground corn infusion resulted in increased hindgut fermentation (indicated by increased fecal VFA concentrations) and induced hindgut acidosis. Hindgut acidosis was associated with decreased ATTD of most nutrients. A systemic inflammatory response was not observed, suggesting that the hindgut epithelium was not severely affected by acidic or barrier damage. Abomasal infusion of ground corn 
increased milk yield, milk protein and lactose yield, N use efficiency, and energy retained in total as well as in fat, but reduced milk fat content. Overall, in this short-term experiment, induced hindgut acidosis was not associated with negative effects on production performance and energy balance, whereas induced metabolic acidosis tended to decrease feed intake and body protein retention; however, long-term studies are needed to further elucidate the impact of hindgut and metabolic acidosis in dairy cattle.

\section{ACKNOWLEDGMENTS}

Mariana Eugania Bustos Vial, Mauricio Alejandro Larios Carranza, and Pablo Andrés Ronda Borzone (students of Wageningen University \& Research, Wageningen, the Netherlands), the staff of the experimental facilities (Teus Bleyenberg, Wim van Ommeren, and Ries Verkerk), the staff of the Animal Nutrition Group (Sven Alferink and Tamme Zandstra), the staff of the Adaptation Physiology Group (Marcel Heetkamp), and the staff of Breeding and Genetics (Rita Hoving; Wageningen Livestock Research, Wageningen, the Netherlands) are gratefully acknowledged for their assistance during the implementation of the experiment, as are the laboratory staff of the Animal Nutrition Group. This research was conducted by Wageningen University \& Research (Wageningen Livestock Research) and commissioned and funded by the Ministry of Agriculture, Nature and Food Quality (The Hague, the Netherlands) within the framework of Policy Support Research theme "Breed \& Feed4Food" (project BF4F-A4 Diet and health in cattle; TKI-AF-14215). The authors have not stated any conflicts of interest.

\section{REFERENCES}

Afzaal, D., M. Nisa, M. A. Khan, and M. Sarwar. 2004. A review on acid base status in dairy cows: Implications of dietary cation-anion balance. Pak. Vet. J. 24:199-202.

Apper-Bossard, E., J. L. Peyraud, P. Faverdin, and F. Meschy. 2006. Changing dietary cation-anion difference for dairy cows fed with two contrasting levels of concentrate in diets. J. Dairy Sci. 89:749760. https://doi.org/10.3168/jds.S0022-0302(06)72136-1.

Apper-Bossard, E., P. Faverdin, F. Meschy, and J. L. Peyraud. 2010. Effects of dietary cation-anion difference on ruminal metabolism and blood acid-base regulation in dairy cows receiving 2 contrasting levels of concentrate in diets. J. Dairy Sci. 93:4196-4210. https: //doi.org/10.3168/jds.2009-2975.

Argenzio, R. A., N. Miller, and W. von Engelhardt. 1975. Effect of volatile ion absorption fatty from acids on water and ion absorption from the goat colon. Am. J. Physiol. 229:997-1002. https:// doi.org/10.1152/ajplegacy.1975.229.4.997.

Aschenbach, J. R., S. Bilk, G. Tadesse, F. Stumpff, and G. Gabel. 2009. Bicarbonate-dependent and bicarbonate-independent mechanisms contribute to nondiffusive uptake of acetate in the ruminal epithelium of sheep. Am. J. Physiol. Gastro. Liver Physiol. 296:G1098-1107. https://doi.org/10.1152/ajpgi.90442.2008.
Bauman, D. E., and J. M. Griinari. 2001. Regulation and nutritional manipulation of milk fat: Low-fat milk syndrome. Livest. Prod. Sci. 70:15-29. https://doi.org/10.1016/S0301-6226(01)00195-6.

Bijl, E., H. J. F. van Valenberg, T. Huppertz, and A. C. M. van Hooijdonk. 2013. Protein, casein, and micellar salts in milk: Current content and historical perspectives. J. Dairy Sci. 96:5455-5464. https://doi.org/10.3168/jds.2012-6497.

Brown, M. S., C. R. Krehbiel, M. L. Galyean, M. D. Remmenga, J. P. Peters, B. Hibbard, J. Robinson, and W. M. Moseley. 2000 Evaluation of models of acute and subacute acidosis on dry matter intake, ruminal fermentation, blood chemistry, and endocrine profiles of beef steers. J. Anim. Sci. 78:3155-3168. https://doi.org/ $10.2527 / 2000.78123155 x$.

Cant, J. P., D. R. Trout, F. Qiao, and N. G. Purdie. 2002. Milk synthetic response of the bovine mammary gland to an increase in the local concentration of arterial glucose. J. Dairy Sci. 85:494-503. https://doi.org/10.3168/jds.S0022-0302(02)74100-3.

Carroll, J. A., R. R. Reuter, C. C. Chase Jr., S. W. Coleman, D. G. Riley, D. E. Spiers, J. D. Arthington, and M. L. Galyean. 2009. Profile of the bovine acute-phase response following an intravenous bolus-dose lipopolysaccharide challenge. Innate Immun. 15:81-89. https://doi.org/10.1177/1753425908099170.

Chan, P. S., J. W. West, J. K. Bernard, and J. M. Fernandez. 2005. Effects of dietary cation-anion difference on intake, milk yield, and blood components of the early lactation cow. J. Dairy Sci. 88:43844392. https://doi.org/10.3168/jds.S0022-0302(05)73125-8.

Charbonneau, E., D. Pellerin, and G. R. Oetzel. 2006. Impact of lowering dietary cation-anion difference in nonlactating dairy cows: A meta-analysis. J. Dairy Sci. 89:537-548. https://doi.org/10.3168/ jds.S0022-0302(06)72116-6.

Ciszuk, P., and T. Gebregziabher. 1994. Milk urea as an estimate of urine nitrogen of dairy cows and goats. Acta Agric. Scand. A Anim. Sci. 44:87-95.

Colucci, P. E., G. K. Macleod, W. L. Grovum, L. W. Cahill, and I. McMillan. 1989. Comparative digestion in sheep and cattle fed different forage to concentrate ratios at high and low intakes. J. Dairy Sci. 72:1774-1785. https://doi.org/10.3168/jds.S0022 -0302(89)79294-8.

Constable, P. D., K. W. Hinchcliff, S. H. Done, and W. Grünberg. 2017. Chapter 8: Diseases of the alimentary tract-Ruminant. Pages 436-621 in Veterinary Medicine: A Textbook of the Diseases of Cattle, Horses, Sheep, Pigs and Goats. 11th ed. Elsevier, St Louis, MO.

Corey, H. E. 2003. Stewart and beyond: New models of acid-base balance. Kidney Int. 64:777-787.

CVB. 2018. Chemische Samenstellingen en Nutritionele Waarden van Voedermiddelen [in Dutch]. CVB (Centraal Veevoederbureau), The Hague, the Netherlands.

Dijkstra, J., J. L. Ellis, E. Kebreab, A. B. Strathe, S. López, J. France, and A. Bannink. 2012. Ruminal pH regulation and nutritional consequences of low pH. Anim. Feed Sci. Technol. 172:22-33. https:// doi.org/10.1016/j.anifeedsci.2011.12.005.

Dubuc, J., T. F. Duffield, K. E. Leslie, J. S. Walton, and S. J. LeBlanc. 2010. Risk factors for postpartum uterine diseases in dairy cows. J. Dairy Sci. 93:5764-5771. https://doi.org/10.3168/jds.2010-3429.

Emmanuel, D. G., K. L. Madsen, T. A. Churchill, S. M. Dunn, and B. N. Ametaj. 2007. Acidosis and lipopolysaccharide from Escherichia coli B:055 cause hyperpermeability of rumen and colon tissues. J. Dairy Sci. 90:5552-5557. https://doi.org/10.3168/jds .2007-0257.

Enemark, J. M., R. J. Jørgensen, and P. S. Enemark. 2002. Rumen acidosis with special emphasis on diagnostic aspects of subclinical rumen acidosis: A review. Vet. ir Zootech. 20:16-29.

Enemark, J. M. D. 2008. The monitoring, prevention and treatment of sub-acute ruminal acidosis (SARA): A review. Vet. J. 176:32-43. https://doi.org/10.1016/j.tvjl.2007.12.021.

Erdman, R. A., R. W. Hemken, and L. S. Bull. 1982. Dietary sodium bicarbonate and magnesium oxide for early postpartum lactating dairy cows: Effects on production, acid-base metabolism, and digestion. J. Dairy Sci. 65:712-731. https://doi.org/10.3168/jds .S0022-0302(82)82259-5. 
Gärtner, T., V. Zoche-Golob, S. Redlberger, P. Reinhold, and K. Donat. 2019. Acid-base assessment of post-parturient German Holstein dairy cows from jugular venous blood and urine: A comparison of the strong ion approach and traditional blood gas analysis. PLoS One 14:e0210948. https://doi.org/10.1371/journal.pone .0210948 .

Gerrits, W. J. J., J. J. G. C. van den Borne, and E. Labussière. 2015. Deriving heat production from gaseous exchange: Validity of the approach. Pages 19-34 in Indirect Calorimetry. Techniques, Computations and Applications. W. J. J. Gerrits and E. Labussière, ed. Wageningen Academic Publishers, Wageningen, the Netherlands.

Gressley, T. F., and L. E. Armentano. 2005. Effect of abomasal pectin infusion on digestion and nitrogen balance in lactating dairy cows. J. Dairy Sci. 88:4028-4044. https://doi.org/10.3168/jds.S0022 -0302(05)73089-7.

Gressley, T. F., and L. E. Armentano. 2007. Effects of low rumendegradable protein or abomasal fructan infusion on diet digestibility and urinary nitrogen excretion in lactating dairy cows. J. Dairy Sci. 90:1340-1353. https://doi.org/10.3168/jds.S0022 -0302(07)71621-1.

Gressley, T. F., M. B. Hall, and L. E. Armentano. 2011. Ruminant nutrition symposium: Productivity, digestion, and health responses to hindgut acidosis in ruminants. J. Anim. Sci. 89:1120-1130. https://doi.org/10.2527/jas.2010-3460.

Heetkamp, M. J. W., S. J. J. Alferink, T. Zandstra, P. Hendriks, H. van den Brand, and W. J. J. Gerrits. 2015. Design of climate respiration chambers, adjustable to the metabolic mass of subjects. Pages 35-56 in Indirect Calorimetry. Techniques, Computations and Applications. W. J. J. Gerrits and E. Labussière, ed. Wageningen Academic Publishers, Wageningen, the Netherlands.

Heijnen, M.-L. A., and A. C. Beynen. 1997. Consumption of retrograded $\left(\mathrm{RS}_{3}\right)$ but not uncooked $\left(\mathrm{RS}_{2}\right)$ resistant starch shifts nitrogen excretion from urine to feces in cannulated piglets. J. Nutr. 127:1828-1832. https://doi.org/10.1093/jn/127.9.1828.

Hu, W., and M. R. Murphy. 2004. Dietary cation-anion difference effects on performance and acid-base status of lactating dairy cows: A meta-analysis. J. Dairy Sci. 87:2222-2229. https://doi.org/10 .3168/jds.S0022-0302(04)70042-9.

Hurley, J. C. 1995. Endotoxemia: Methods of detection and clinical correlates. Clin. Microbiol. Rev. 8:268-292. https://doi.org/10 $.1128 /$ CMR. 8.2.268.

Huzzey, J. M., T. F. Duffield, S. J. LeBlanc, D. M. Veira, D. M. Weary, and M. A. G. von Keyserlingk. 2009. Short communication: Haptoglobin as an early indicator of metritis. J. Dairy Sci. 92:621-625. https://doi.org/10.3168/jds.2008-1526.

Immig, I. 1996. The rumen and hindgut as source of ruminant methanogenesis. Environ. Monit. Assess. 42:57-72. https://doi.org/10 $.1007 / \mathrm{BF} 00394042$.

International Organization for Standardization. 1998. ISO 9831:1998. Animal feedstuffs, animal products, and feces or urine - Determination of gross caloric values-Bomb calorimeter method. International Organization for Standardization, Geneva, Switzerland.

International Organization for Standardization. 2013. ISO 9622:2013. Milk and liquid milk products. Guidelines for the application of mid-infrared spectrometry. International Standards Organization, Geneva, Switzerland.

Iwaniuk, M. E., and R. A. Erdman. 2015. Intake, milk production, ruminal, and feed efficiency responses to dietary cation-anion difference by lactating dairy cows. J. Dairy Sci. 98:8973-8985. https: //doi.org/10.3168/jds.2015-9949.

Jenkins, T. C., W. C. Bridges Jr., J. H. Harrison, and K. M. Young. 2014. Addition of potassium carbonate to continuous cultures of mixed ruminal bacteria shifts volatile fatty acids and daily production of biohydrogenation intermediates. J. Dairy Sci. 97:975-984. https://doi.org/10.3168/jds.2013-7164.

Knowlton, K. F., T. E. Dawson, B. P. Glenn, G. B. Huntington, and R. A. Erdman. 1998. Glucose metabolism and milk yield of cows infused abomasally or ruminally with starch. J. Dairy Sci. 81:3248 3258. https://doi.org/10.3168/jds.S0022-0302(98)75889-8.
Kolver, E. S., and M. J. de Veth. 2002. Prediction of ruminal pH from pasture-based diets. J. Dairy Sci. 85:1255-1266. https://doi.org/10 .3168/jds.S0022-0302(02)74190-8.

Li, S., E. Khafipour, D. O. Krause, A. Kroeker, J. C. RodriguezLecompte, G. N. Gozho, and J. C. Plaizier. 2012. Effects of subacute ruminal acidosis challenges on fermentation and endotoxins in the rumen and hindgut of dairy cows. J. Dairy Sci. 95:294-303. https://doi.org/10.3168/jds.2011-4447.

Li, S., I. Yoon, M. Scott, E. Khafipour, and J. C. Plaizier. 2016. Impact of Saccharomyces cerevisiae fermentation product and subacute ruminal acidosis on production, inflammation, and fermentation in the rumen and hindgut of dairy cows. Anim. Feed Sci. Technol. 211:50-60. https://doi.org/10.1016/j.anifeedsci.2015.10.010.

Metzler-Zebeli, B. U., S. Schmitz-Esser, F. Klevenhusen, L. Podstatzky-Lichtenstein, M. Wagner, and Q. Zebeli. 2013. Grain-rich diets differently alter ruminal and colonic abundance of microbial populations and lipopolysaccharide in goats. Anaerobe 20:65-73. https: //doi.org/10.1016/j.anaerobe.2013.02.005.

Mulligan, F. J., and M. L. Doherty. 2008. Production diseases of the transition cow. Vet. J. 176:3-9. https://doi.org/10.1016/j.tvjl.2007 .12 .018 .

Nichols, K., A. Bannink, S. Pacheco, H. J. van Valenberg, J. Dijkstra, and $\mathrm{H}$. van Laar. 2018. Feed and nitrogen efficiency are affected differently but milk lactose production is stimulated equally when isoenergetic protein and fat is supplemented in lactating dairy cow diets. J. Dairy Sci. 101:7857-7870. https://doi.org/10.3168/jds .2017-14276.

Nichols, K., J. Dijkstra, H. van Laar, S. Pacheco, H. J. van Valenberg, and A. Bannink. 2019. Energy and nitrogen partitioning in dairy cows at low or high metabolizable protein levels is affected differently by postrumen glucogenic and lipogenic substrates. J. Dairy Sci. 102:395-412. https://doi.org/10.3168/jds.2018-15249.

Ørskov, E. R., C. Fraser, and R. N. B. Kay. 1969. Dietary factors influencing the digestion of starch in the rumen and small and large intestine of early weaned lambs. Br. J. Nutr. 23:217-226. https:// doi.org/10.1079/BJN19690029.

Owens, F. N., R. A. Zinn, and Y. K. Kim. 1986. Limits to starch digestion in the ruminant small intestine. J. Anim. Sci. 63:1634-1648. https://doi.org/10.2527/jas1986.6351634x.

Peaker, M. 1983. Secretion of ions and water. Pages 285-305 in Biochemistry of Lactation. T. B. Mepham, ed. Elsevier Science Publishers B.V., Amsterdam, the Netherlands.

Plaizier, J. C., M. Danesh Mesgaran, H. Derakhshani, H. Golder, E. Khafipour, J. L. Kleen, I. Lean, J. Loor, G. Penner, and Q. Zebeli. 2018. Review: Enhancing gastrointestinal health in dairy cows. Animal 12(Suppl. 2):s399-s418. https://doi.org/10.1017/ S1751731118001921.

Plaizier, J. C., E. Khafipour, S. Li, G. N. Gozho, and D. O. Krause. 2012. Subacute ruminal acidosis (SARA), endotoxins and health consequences. Anim. Feed Sci. Technol. 172:9-21. https://doi.org/ 10.1016/j.anifeedsci.2011.12.004.

Plaizier, J. C., S. Li, A. M. Danscher, H. Derakshani, P. H. Andersen, and E. Khafipour. 2017. Changes in microbiota in rumen digesta and feces due to a grain-based subacute ruminal acidosis (SARA) challenge. Microb. Ecol. 74:485-495. https://doi.org/10.1007/ s00248-017-0940-z.

Qumar, M., R. Khiaosa-ard, F. Klevenhusen, J. C. Plaizier, and Q. Zebeli. 2017. Gastrointestinal endotoxin and metabolic responses in cows fed and recovered from two different grain-rich challenges. Livest. Sci. 203:120-123. https://doi.org/10.1016/j.livsci.2017.07 .015 .

Reynolds, C. K. 2006. Production and metabolic effects of site of starch digestion in dairy cattle. Anim. Feed Sci. Technol. 130:7894. https://doi.org/10.1016/j.anifeedsci.2006.01.019.

Reynolds, C. K., S. B. Cammell, D. J. Humphries, D. E. Beever, J D. Sutton, and J. R. Newbold. 2001. Effects of postrumen starch infusion on milk production and energy metabolism in dairy cows. J. Dairy Sci. 84:2250-2259. https://doi.org/10.3168/jds.S0022 $-0302(01) 74672-3$. 
Reynolds, C. K., D. J. Humphries, S. B. Cammell, J. Benson, J. D. Sutton, and D. E. Beever. 1998. Effects of abomasal wheat starch infusion on splanchnic metabolism and energy balance of lactating dairy cows. Page 39 in: Energy Metabolism of Farm Animals, Proceedings of the 14th Symposium on Energy Metabolism. K. J. McCracken, E. F. Unsworth, A. R. G. Wylie, ed. CAB International, Wallingford, UK.

Rius, A. G., J. A. D. R. N. Appuhamy, J. Cyriac, D. Kirovski, O. Becvar, J. Escobar, M. L. McGilliard, B. J. Bequette, R. M. Akers, and M. D. Hanigan. 2010a. Regulation of protein synthesis in mammary glands of lactating dairy cows by starch and amino acids. J. Dairy Sci. 93:3114-3127. https://doi.org/10.3168/jds.2009 -2743 .

Rius, A. G., M. L. McGilliard, C. A. Umberger, and M. D. Hanigan. 2010b. Interactions of energy and predicted metabolizable protein in determining nitrogen efficiency in the lactating dairy cow. J. Dairy Sci. 93:2034-2043. https://doi.org/10.3168/jds.2008-1777.

Roche, J. R., D. E. Dalley, P. J. Moate, C. Grainger, M. Rath, and F. O'Mara. 2003. Dietary cation-anion difference and the health and production of pasture-fed dairy cows. 1 . Dairy cows in early lactation. J. Dairy Sci. 86:970-978. https://doi.org/10.3168/jds.S0022 $-0302(03) 73680-7$.

Roche, J. R., K. A. Macdonald, K. E. Schütz, L. R. Matthews, G. A. Verkerk, S. Meier, J. J. Loor, A. R. Rogers, J. McGowan, S. R. Morgan, S. Taukiri, and J. R. Webster. 2013. Calving body condition score affects indicators of health in grazing dairy cows. J. Dairy Sci. 96:5811-5825. https://doi.org/10.3168/jds.2013-6600.

Roche, J. R., S. Petch, and J. K. Kay. 2005. Manipulating the dietary cation-anion difference via drenching to early-lactation dairy cows grazing pasture. J. Dairy Sci. 88:264-276. https://doi.org/10 .3168/jds.S0022-0302(05)72684-9.

Rulquin, H., S. Rigout, S. Lemosquet, and A. Bach. 2004. Infusion of glucose directs circulating amino acids to the mammary gland in well-fed dairy cows. J. Dairy Sci. 87:340-349. https://doi.org/10 .3168/jds.S0022-0302(04)73173-2.

Schotman, A. J. H. 1971. The acid-base balance in clinically healthy and diseased cattle. Neth. J. Vet. Sci. 4:5-24.

Shennan, D. B., and M. Peaker. 2000. Transport of milk constituents by the mammary gland. Physiol. Rev. 80:925-951. https://doi.org/ 10.1152/physrev.2000.80.3.925.

Spek, J. W., J. Dijkstra, G. van Duinkerken, and A. Bannink. 2013. A review of factors influencing milk urea concentration and its relationship with urinary urea excretion in lactating dairy cattle. J. Agric. Sci. 151:407-423. https://doi.org/10.1017/ S0021859612000561.

Stewart, P. A. 1983. Modern quantitative acid-base chemistry. Can. J. Physiol. Pharmacol. 61:1444-1461. https://doi.org/10.1139/y83 $-207$.

Tao, S., Y. Duanmu, H. Dong, Y. Ni, J. Chen, X. Shen, and R. Zhao. 2014. High concentrate diet induced mucosal injuries by enhancing epithelial apoptosis and inflammatory response in the hindgut of goats. PLoS One 9:e111596.

Tucker, W. B., G. A. Harrison, and R. W. Hemken. 1988. Influence of dietary cation-anion balance on milk, blood, urine, and rumen fluid in lactating dairy cattle. J. Dairy Sci. 71:346-354. https://doi .org/10.3168/jds.S0022-0302(88)79563-6.

van Duinkerken, G., M. C. Blok, A. Bannink, J. W. Cone, J. Dijkstra, A. M. van Vuuren, and S. Tamminga. 2011. Update of the Dutch protein evaluation system for ruminants: The DVE/ OEB2010 system. J. Agric. Sci. 149:351-367. https://doi.org/10 .1017/S0021859610000912.

Van Es, A. J. H. 1978. Feed evaluation for ruminants. I. The systems in use from May 1977-onwards in the Netherlands. Livest. Prod. Sci. 5:331-345. https://doi.org/10.1016/0301-6226(78)90029-5.

van Gastelen, S., E. C. Antunes-Fernandes, K. A. Hettinga, G. Klop, S. J. J. Alferink, W. H. Hendriks, and J. Dijkstra. 2015. Enteric methane production, rumen volatile fatty acid concentrations, and milk fatty acid composition in lactating Holstein-Friesian cows fed grass silage- or corn silage-based diets. J. Dairy Sci. 98:1915-1927. https://doi.org/10.3168/jds.2014-8552.

van Knegsel, A. T. M., H. van den Brand, J. Dijkstra, W. M. van Straalen, R. Jorritsma, S. Tamminga, and B. Kemp. 2007. Effect of glucogenic vs. lipogenic diets on energy balance, blood metabolites, and reproduction in primiparous and multiparous dairy cows in early lactation. J. Dairy Sci. 90:3397-3409. https://doi.org/10 $.3168 /$ jds.2006-837.

van Zijderveld, S. M., B. Fonken, J. Dijkstra, W. J. J. Gerrits, H. B. Perdok, W. Fokkink, and J. R. Newbold. 2011. Effects of a combination of feed additives on methane production, diet digestibility, and animal performance in lactating dairy cows. J. Dairy Sci 94:1445-1454. https://doi.org/10.3168/jds.2010-3635.

Wang, K., X. Nan, P. Zhao, W. Liu, J. K. Drackley, S. Liu, K. Zhang, and D. Bu. 2018. Effects of low dietary cation-anion difference induced by ruminal ammonium chloride infusion on performance, serum, and urine metabolites of lactating dairy cows. Asian-Australas. J. Anim. Sci. 31:677-685. https://doi.org/10.5713/ajas.17 .0530 .

Wells, J. E., and J. B. Russell. 1996. Why do many ruminal bacteria die and lyse so quickly? J. Dairy Sci. 79:1487-1495. https://doi .org/10.3168/jds.S0022-0302(96)76508-6.

West, J. W., C. E. Coppock, D. H. Nave, J. M. Labore, L. W. Greene, and T. W. Odom. 1987. Effects of potassium carbonate and sodium bicarbonate on rumen function in lactating Holstein cows. J. Dairy Sci. 70:81-90. https://doi.org/10.3168/jds.S0022-0302(87)79982-2.

Williams, E. J. 1949. Experimental designs balanced for the estimation of residual effects of treatments. Aust. J. Sci. Res., A 2:149-168. https://doi.org/10.1071/CH9490149.

Zimpel, R., M. B. Poindexter, A. Vieira-Neto, E. Block, C. D. Nelson, C. R. Staples, W. W. Thatcher, and J. E. P. Santos. 2018. Effect of dietary cation-anion difference on acid-base status and dry matter intake in dry pregnant cows. J. Dairy Sci. 101:8461-8475. https:// doi.org/10.3168/jds.2018-14748.

Zom, R. L. G., G. André, and A. M. van Vuuren. 2012. Development of a model for the prediction of feed intake by dairy cows: 1 . Prediction of feed intake. Livest. Sci. 143:43-57. https://doi.org/10 .1016/j.livsci.2011.08.014.

\section{ORCIDS}

Sanne van Gastelen () https://orcid.org/0000-0003-4547-8449 Jan Dijkstra ๑ https://orcid.org/0000-0003-3728-6885

Kelly Nichols @ (ㄴ) https://orcid.org/0000-0001-6062-7460 